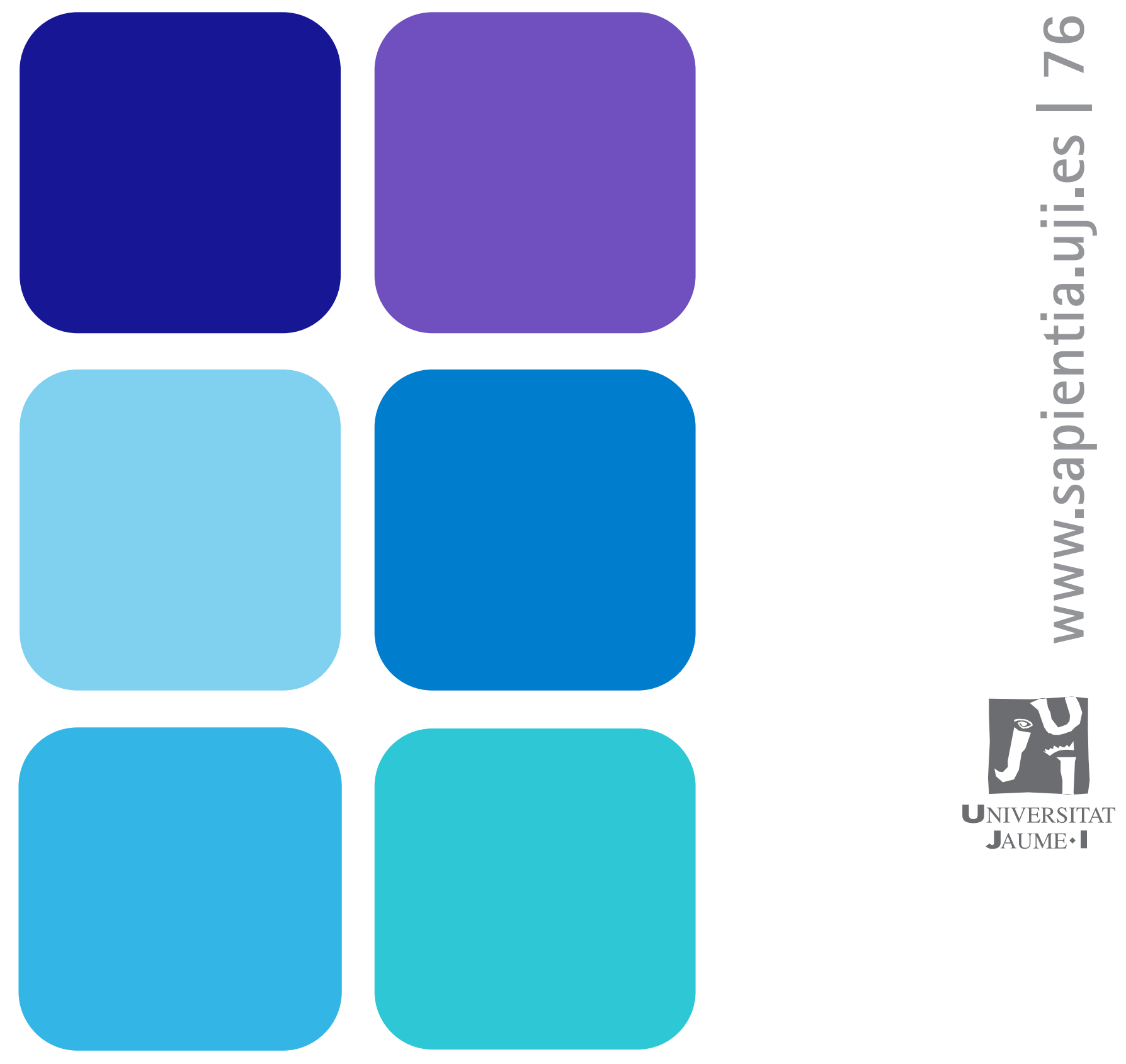

\title{
The Musical Theatre as a Vehicle of Learning: an Educational Innovation Project at the University
}

Santiago Pérez-Aldeguer 


\section{The Musical Theatre as a Vehicle of Learning: an Educational Innovation Project at the University}

Santiago Pérez-Aldeguer

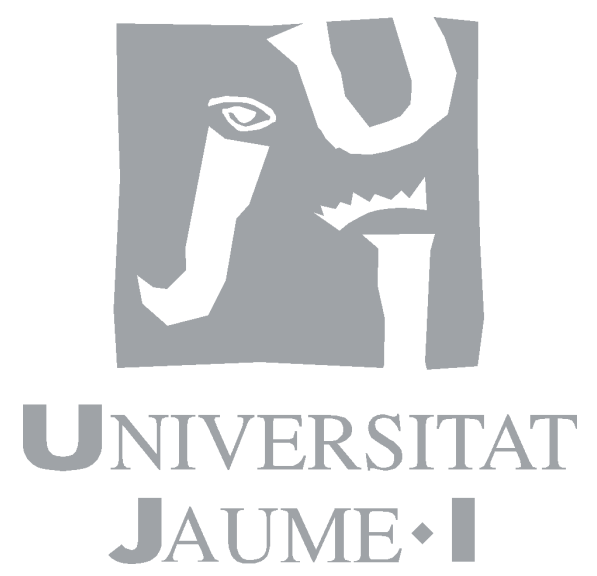

Departament d'Educació

Codis d'assignatura MP1022 / 616 
Edita: Publicacions de la Universitat Jaume I. Servei de Comunicació i Publicacions Campus del Riu Sec. Edifici Rectorat i Serveis Centrals. 12071 Castelló de la Plana http://www.tenda.uji.es e-mail: publicacions@uji.es

Col·lecció Sapientia 76, versió en anglès

Colllecció Sapientia 77, versió en castellà

www.sapientia.uji.es

Primera edició, 2013

ISBN: 978-84-695-7656-4

17 Publicacions de la Universitat Jaume I és una editorial membre de l'UNE, cosa que en garanteix la difusió de les obres en els àmbits nacional i Uní́s de Edtoriates internacional. www.une.es

\section{(c) (1) (2)}

Reconeixement-CompartirIgual

CC BY-SA

Aquest text està subjecte a una llicència Reconeixement-Compartirlgual de Creative Commons, que permet copiar, distribuir i comunicar públicament l'obra sempre que s'especifique l'autor i el nom de la publicació fins i tot amb objectius comercials i també permet crear obres derivades, sempre que siguen distribuïdes amb aquesta mateixa llicència. http://creativecommons.org/licenses/by-sa/3.0/legalcode 


\section{TABLE OF CONTENTS}

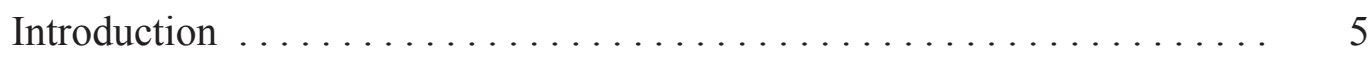

Chapter 1

Two learning models through the musical theatre ............... 7

1.1. Introduction . . . . . . . . . . . . . . . . . . . . . 9

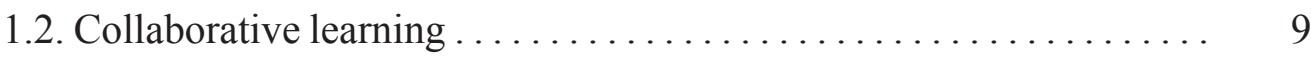

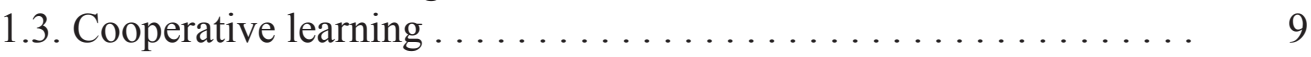

1.4. Cooperative vs. collaborative learning ................ 10

Chapter 2

The musical theatre as a learning vehicle $\ldots \ldots \ldots \ldots \ldots \ldots \ldots \ldots$

2.1. Introduction . . . . . . . . . . . . . . . . . . . . . . . 15

2.2. A brief contextualisation of the musical theatre ........... 15

2.3. The musical theatre as an educational tool .............. 15

2.4. Benefits of the musical theatre for education . . . . . . . . . . . 17

2.5. Contributions of the musical theatre to Music Education ......... 18

Chapter 3

Organisational aspects of the musical theatre $\ldots \ldots \ldots \ldots \ldots \ldots \ldots 21$

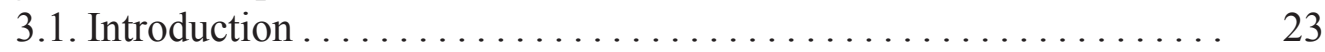

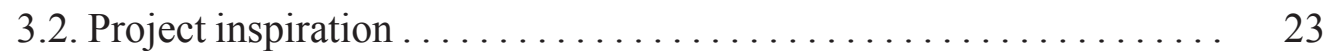

3.3. Musical theatre production for educational purposes ......... 24

3.4. Some musical theatre roles for educational purposes . . . . . . . . 26

Chapter 4

Pilot project and collaborative learning .................... 29

4.1. Introduction . . . . . . . . . . . . . . . . . . . . . . 31

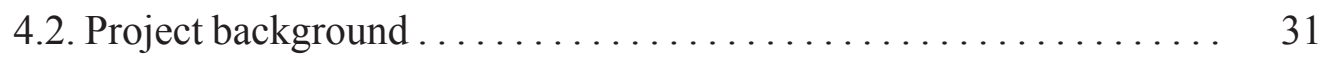

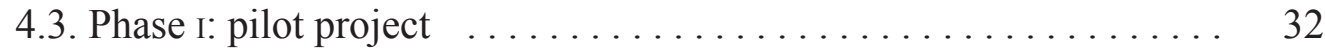

4.4. Phase II: Group 1 collaborative project. .............. 33

Chapter 5

Cooperative learning. ................................ 39

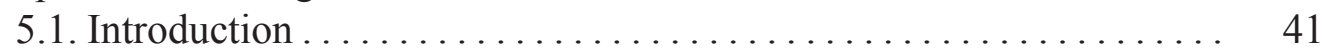

5.2. Phase III: cooperative project ................. 41

5.3. Development of the cooperative project .............. 44

5.4. Evaluation of the cooperative project ................ 48

5.5. Some examples of the cooperative project .......... 51 


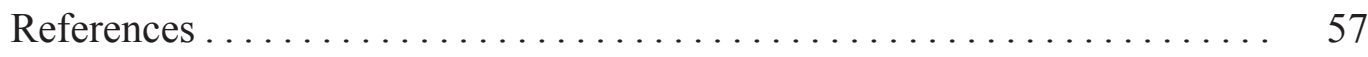

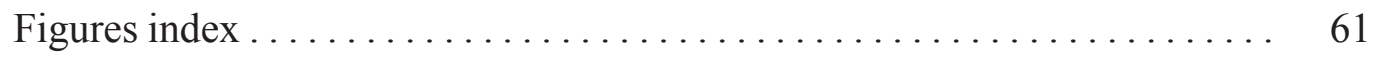

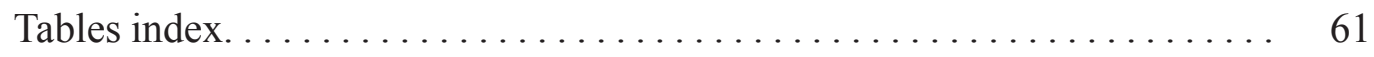




\section{Introduction}

This work aims to provide students with the methodological guidelines used in the Musical Expression Pedagogy subject matter. It has been divided into five chapters that address the different theoretical and practical aspects of the project.

In the first chapter, differences and similarities between collaborative and cooperative learning are discussed. Both have been taken as educational models of this project. Therefore, the most significant characteristics of both collaborative and cooperative learning are addressed.

Chapter 2 introduces the musical theatre as a learning vehicle in the formal education field. For this purpose, various musical theatre definitions are examined. Similarly, several authors justify why working with the musical theatre in the educational environment is interesting. Finally, this chapter ends by concluding the educational benefits and musical theatre contributions to the music education field.

Chapter 3 presents the LOVA project, the inspirational source of the project developed in Chapters 4 and 5. The production processes of a musical theatre from an educational perspective with the different constituents and tasks to be performed are discussed. Finally, it finishes with some examples of roles to develop the musical theatre project for educational purposes.

Chapter 4 is an overview of the project background. For this purpose, the work is divided into three phases which refer to each academic year in which it took place.

Chapter 5 provides specific guidelines to guide students to undertake a project of this nature. Therefore, the phases conducted in the final project stage are presented. The working model used is a cooperative one, thus both the development and evaluation of the model used are described. Lastly, some examples of the cooperative project conducted during academic year 2011/2012 are provided.

Finally, it should be noted that the project does not end with these three issues, but is still ongoing in order to achieve constant improvement. 
CHAPTER 1

\section{Two learning models through the musical theatre}

1.1. Introduction

1.2. Collaborative learning

1.3. Cooperative learning

1.4. Cooperative vs. Collaborative learning 


\subsection{Introduction}

This chapter deals with the differences and similarities between collaborative and cooperative learning, both of which are implemented as educational models of this project. Thus, the most significant characteristics of collaborative and cooperative learning are addressed.

\subsection{Collaborative learning}

Collaborative learning refers to participants' commitment to make coordinated efforts to solve a problem where groups shoulder almost all the responsibility to achieve the goal (Dillenbourg, Baker, Blaye \& O’Malley, 1996).

\subsection{Cooperative learning}

Cooperative learning refers to work done in small groups where students enhance their own learning and that of others together (Johnson \& Johnson, 2001). This is accomplished by distributing tasks among students, who are all responsible for part of the information required to solve the problem. The teacher monitors the group to achieve the goal (Dillenbourg, Baker, Blaye \& O’Malley, 1996).

Research into cooperative learning is one of the greatest achievements in the history of educational research. Initial studies emerged in the early twentieth century, but it was not until the 1970's that quantity and quality increased. Perhaps one of the achievements has been to make people aware of the notion that: «cooperation, competition and individualism are not part of the genetic code: they are learned, and therefore taught» (Traver \& Rodríguez, 2011:10).

The most common characteristics of cooperative learning are (Johnson, Johnson \& Smith, 1991; Duplass, 2006):

1. Educator's supervision. The teacher supervises group activity to ensure that students have understood the task.

2. Heterogeneous group. Groups are created according to different abilities, personalities, etc.

3. Positive interpedendence. Group goals are established and work focuses on a final learning outcome. Students perform tasks which they feel they can accomplish only if all the group members contribute to the effort required.

4. Face-to-face interaction. Students are encouraged to use verbal and noncommunication to solve problems. As part of the activity, time and space are provided for students to meet with group members and to provide assistance in learning tasks. 
5. Individual responsibility. Students are responsible for their tasks and also for providing help to the group to achieve learning goals. This responsibility is accomplished through student roles. Students must learn their role and must demonstrate that they have learned to master it. The group should facilitate each member's learning, but everyone should be responsible enough to demonstrate their own learning.

6. Social skills. The teacher must establish rules for all students to be respectful, to speak appropriately in the classroom, and to make good use of their time during group interactions. Students have the opportunity to practice different group skills, such as development of confidence, effective communication and conflict resolution.

7. Group functioning. Students engage in reflecting on how the group worked during the activity. Thus, a space is created to reflect on the processes that facilitated or exacerbated the group's goals.

8. Evaluation. Activities must include individual and group evaluations.

\subsection{Cooperative vs. collaborative learning}

The terms cooperative and collaborative are often used without distinction. However, there are several differences between both concepts. Millis (1996) states that cooperative learning is a generic term used to describe a situation where students work together in small groups to help each other to learn. Meanwhile, Johnson and Johnson (2001) indicate that cooperative learning means working in small groups in such a way that students enhance their own learning and that of others together.

However, Panitz (1996) clearly distinguishes between cooperative and collaborative learning: collaboration is an interaction philosophy and a lifestyle, where everyone is responsible for their own actions, including learning and respect for peers' abilities and contributions. Cooperation is an interaction structure designed to facilitate the achievement of a specific goal through people working in groups where the teacher completely controls the situation.

Moreover, authors like Dillenbourg, Baker, Blaye and O'Malley (1996) differentiate both concepts by stating that collaboration involves participants' commitment to making coordinated efforts to solve a problem, whereas cooperative learning is achieved by participants sharing tasks, where everyone is responsible for one part of the information required to solve the problem.

Thus in the collaborative model, groups assume most of the responsibility to achieve the goal and they determine whether they have enough information to answer the problem. Otherwise, they look for other sources, such as scientific journals, books, videos or the Internet. To obtain additional information, the work 
is divided among group members. The teacher assesses each group's process and makes suggestions according to the results obtained. Likewise, the final product is determined by all the groups based on the teacher's advice.

In the cooperative model, however, the teacher has full control of the class. Thus, the teacher can use specific strategies to facilitate group interaction. The goal can be a specific product such as a performance. Therefore, students set their target by considering the material available. 


\section{CHAPTER 2}

\section{The musical theatre as a learning vehicle}

2.1. Introduction

2.2. A brief contextualisation of the musical theatre

2.3. The musical theatre as an education tool

2.4. Benefits of the musical theatre for education

2.5. Contributions of the theatre to Music Education 


\subsection{Introduction}

This chapter addresses the musical theatre as a vehicle for learning in the formal education field. Various definitions of the musical theatre are presented, and why working the musical theatre from the educational field is interesting is justified. Finally, it ends with the educational benefits and contributions of the musical theatre in the music education field.

\subsection{A brief contextualisation of the musical theatre}

The musical theatre is a theatre style that combines songs, spoken dialogues, performances and dance. Since the twentieth century, it was merely called musical. The story and the emotional humour, pathos, love or anger content of the works are communicated through words, music, movement and the technical aspects of the show as a complete whole (Walsh \& Platt, 2003).

The musical theatre emerged in the late eighteenth and early nineteenth centuries in the USA as a form of entertainment. Eventually, it became a powerful means of popular and politic expression, where tensions and reconciliations were articulated in everyday relationships between people and society. The musical theatre is associated with the social, cultural and political identity of America. It was often rejected as simple entertainment that was inseparably linked to the sense of the New World and the emblem of modern culture. In addition, it includes materials of various genres, ranging from melodrama to the musical theatre such as West Side Story. Consequently, the musical theatre can represent a vehicle for the social and political analysis of different ages (Walsh \& Platt 2003).

Research into the musical theatre in education is quite scarce, mainly because musicals were not created for schools, but for professional artists (Howard, 1990). Yet it is clear that the musical theatre is one of the most expected and coveted activities in the educational field (Sjoerdsma, 2004; Llopis Bueno, 2011). This was evidenced when the current project was suggested to students along with other different artistic genres, when the vast majority chose the musical theatre.

\subsection{The musical theatre as an educational tool}

Research on the musical theatre reveals its influence on social benefit for those who practice it. However, research into the musical theatre in higher education is scarce. Therefore, different aspects of the musical theatre from other education areas are presented.

If the musical theatre is properly structured, it better fits the overall scheme of education than any other form of artistic activity (Fields, 1970). Sometimes, the musical theatre is appreciated more as aesthetic education (Grote, 1986) and seems to provide an answer to educators who strive for the integration of artistic 
experiences into the education system (Howard, 1990). Likewise, the musical theatre is one of the most popular events of the academic year (Sjoerdsma, 2004), and schools have shown increased interest in it. Some institutions have considered the musical theatre to be a tool to attract students from other knowledge areas to music (Watkins, 2005).

The vocal part in the musical theatre is often the most common concern for the music teacher (Williams, 2003). Thus, training that requires specific skills as an effective means of education becomes apparent (Snider, 1995). Hence curriculum development should not be rigid as it might imply the removal of practical experiences such as the musical theatre (Timmons, 2004). Teaching the musical theatre must entail a certain level of flexibility for it to adapt to different school climates. The pedagogical training of future educators must be adequate enough to allow a successful musical theatre, and to adapt to each school's individual needs without following a curriculum that is too rigid.

As educators, we work to overcome curriculum deficiencies while demanding a more flexible curriculum for our students at the same time (Snider, 1995). They feel a certain amount of frustration when their grades do not reflect the efforts they have invested. Sometimes students blame lack of teacher preparation and badly managed time (Boyes, 2003). Moreover, it is necessary to enhance the teacher's role in the musical theatre. Van Houten (1999) discusses the differences between successful and unsuccessful musical theatre programmes by attributing the teacher preparation variable as one of the most important factors of success.

Those experiences acquired through different musical theatre programmes highlight that the teacher highly influences the quality of education (Van Houten, 1999). Van Houten (1999) observed various musical theatre programmes which differed almost entirely due to the coordinator. Thus, the teacher becomes a substantially important tool before, during and after performing the music theatre. Van Houten's (1999) results reveal how a better coordinated teacher involves both parents and the educational community to become part of the production process (Van Houten, 1999).

Those responsible for contributing to the success of the musical theatre experience are largely organisers (Watkins, 2005). Therefore, it is vital to train competent teachers in the learning process by means of the musical theatre, which will better guarantee that students will be living this exciting process positively and without distress. Van Houten (1999) concludes that educators should provide their students with rich educational musical theatre experiences. Unfortunately, this does not often happen, particularly because adequate resources are not available. However, for many students the social and personal benefits inherent to combined efforts seem to compensate any programme deficiencies. These are some of the main reasons why many students invest a lot of time and energy in an extracurricular musical theatre programme (Van Houten, 1999). 


\subsection{Benefits of the musical theatre for education}

According to Hower (1999), students' experiences in the musical theatre have received little attention. In fact, the music education literature lacks examples which identify students' perspectives, save a few exceptions like Llopis Bueno (2011). Likewise, research works focus on performancing musicals as an extracurricular activity, and not as part of formal education.

The musical theatre provides noticeable benefits for students' education (Sample, 1964), since it goes beyond traditional classroom work. In no other discipline are students invited to participate in a variety of complete tasks as they do with the musical theatre, where they develop skills for very different areas of life. Heinig (2001) observes that students improve balance, self-awareness, confidence, selfdiscipline and communication skills during the process. Snider (1995) suggests that the musical theatre helps increase confidence in both students and teachers to help them take risks and make decisions. Sample (1964) indicates that participation in a musical can be an important contribution to students' search for identity. However, it is certain that students enjoy a socially positive educational experience (Van Houten, 1999) within a reflective learning process (Boyes, 2003), which provides a huge sense of accomplishment.

Naturally, the results of students' musical theatre performance will be always inferior to those of a professional, but it is still worth doing (Laster, 2001). Students are commited to the process, which means they wish to repeat the experience the following year (Boyes, 2003). The emotional attachment to the experience is overwhelming. Students' reactions to the musical theatre experience reflect their own educational benefits. By way of example, after performing the musical theatre, students' self-confidence and their confidence in peers increased, they felt a sense of success, friendships were reinforced, and they made new ones (Boyes, 2003). Students apparently need to feel satisfied with their performance. However, through feedback from peers and teacher's support, this experience is maximised (Van Houten, 1999). Thus, the degree of individual involvement in the project is proportional to the enjoyment that students get out of the process and its results (Boyes, 2003).

The appeal of the musical theatre for students not only stems from the interdisciplinary nature of the project (Lynch, 1994), but is also due to the musical theatre, and new like-minded friendships are created. For example, one participant in Boyes' (2003) study joined a group with more affinities for him as a result of their participation in a musical theatre. Moreover, the appeal of the musical format drives students to strive for perfection (Watkins, 2005) in each rehearsal and performance, which provides values like perseverance or effort. As a result of these experiences, students clearly mature socially (Sample, 1964). Likewise, most students develop tolerance and understanding (Watkins, 2005), as well as a clearer understanding of how to address challenges in life. Other areas affected by 
participating in a musical theatre are self-concept and personal growth (Watkins, 2005), self-confidence, social interaction, (Boyes, 2003), motivation, attitude and academic performance (Van Houten, 1999).

Fields (1970) associates enhanced social maturity with good citizenship qualities. These qualities include the development of individual initiative and group cooperation, respect for authority, respect for others' achievements, punctuality, and loyalty. Sense of group and belonging is one of the many benefits of producing a musical theatre in the educational field (Boyes, 2003). Thus, the students in the group who perform a musical theatre feel especially close (Watkins, 2005; Leist, 1958). Students create a community, a family (Timmons, 2004), by developing social relationships and feelings of responsibility and cooperation. The whole process of creating a musical theatre elicits a common goal in each student which provides the group with a common position to achieve the goal.

\subsection{Contributions of the musical theatre to Music Education}

Music education standards are tools to critically reflect on transdisciplinary learning. The success of education in schools depends largely on the effectiveness of Universities. Thus, educators who train future teachers are obliged to learn new strategies and to rethink their assessment to better prepare students. Music teachers are often reluctant to global teaching approaches. In many cases, teacher quality is judged through school festivals (Frederickson, 2010).

There are research works which support that the integration of different knowledge areas creates connections that lead students to a deeper understanding of knowledge (Drake and Burns, 2004). These areas were worked through musical theatre (see chapter 5). This means that any music teacher must be competent in all nine areas described by Frederickson (2010), these being:

1. Singing, Alone and with Others, a Varied Repertoire of Music. This activity seems to be eluded by many educators. However, it is relatively easy to achieve through musical theatre work. In the musical theatre, the choir's participation implies that all the company members must sing in one way (alone) or another (as a group).

2. Playing Instruments, Alone and with Others, a Varied Repertoire of Music. This activity is truly useful for students to create a varied repertoire on music through the musical theatre. They transcribe and arrange different styles and musical periods.

3. Improvising Melodies, Variations, and Accompaniments. There are musical genres with implicit improvisation, such as African music or jazz. Through 
the compositions created or arranged by students, activities are done that encourage improvisation, variation and accompaniment.

4. Composing and Arranging Music. In the company, a composer-arranger role exists, but this should not be performed exclusively by one person. In any case, arrangements and compositions must be monitored by all the group members. Guidelines may derive from the elements constituting the company. For example, if there is a guitar and a piano in the company, the arrangement will contain these instruments. However, recycled instruments and the body itself can be used as a musical instrument.

5. Reading and Notating Music. Through musical creation, different patterns of African music can be performed by oral transmission. Each student has the chance to write those patterns for the purpose of remembering them. Therefore, students understand the musical literacy function from necessity.

6. Listening to, Analysing, and Describing Music. In music, the ability to listen is particularly important. Likewise by creating a musical theatre, students acquire critical capability. For example, when attempting to arrange a musical theme, it is necessary to have musical analysis tools and aesthetic criteria beyond the usual «I like it or I don't like it.»

7. Evaluating Live Music and Music Performances. The great enthusiasm involved when cooperatively performing a musical theatre where fragments of both live and recorded music creates an assessment in which company members will assess each other constructionally.

8. Understanding the Relationships between Music, other Arts, and Disciplines outside the Arts. Costa (1993) states that knowledge is faster acquired and better remembered when presented in a meaningful context. For example, dimensions where performance is staged can be measured, which helps find a relationship between music and mathematics. Through musical theatre work, these and other connections are made with relative ease.

9. Understanding Music in Relationship to History and Culture. Music belongs to a specific context and, when studying it, it is inevitably related to history and culture. During the musical theatre creation, the musical context is especially relevant to understand the historical, cultural and social development in which the work is staged. 
Figure 1 illustrates a summary of basic competences of the subject matter that this project addresses: Teaching Musical Expression

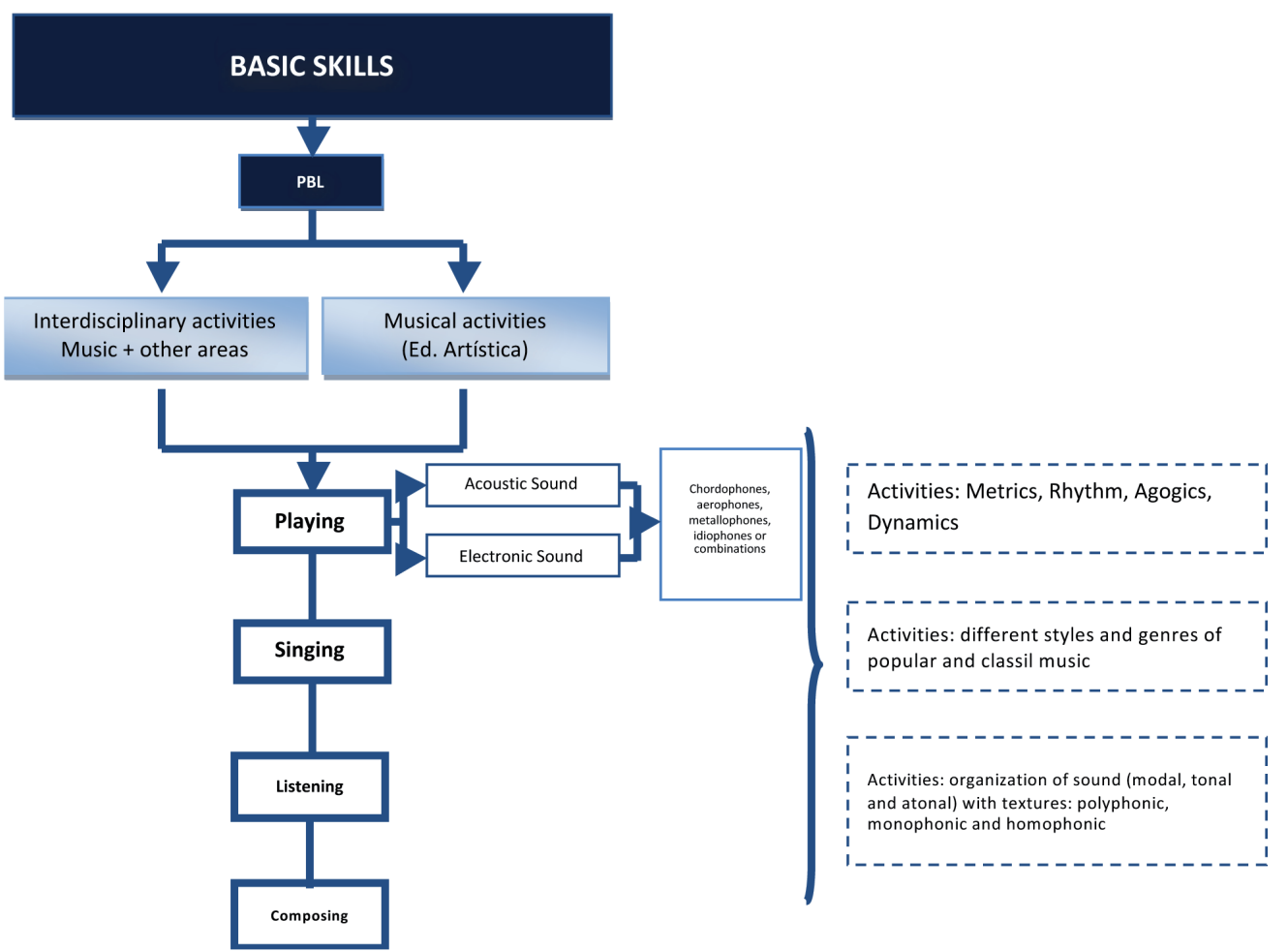

Figure 1. Basic skills of the subject matter (Pérez Aldeguer, 2012:152) 


\section{CHAPTER 3}

\section{Organisational aspects of the musical theatre}

3.1. Introduction

3.2. Project inspiration

3.3. Musical theatre production for educational purposes

3.4. Some musical theatre roles for educational purposes 


\subsection{Introduction}

The third chapter presents the LOVA project, a source of inspiration for the present project, as developed in chapters 4 and 5 . The production processes of a musical theatre are discussed from an educational viewpoint with different elements and tasks to be performed. Finally, it ends by presenting some examples of musical theatre roles with educational purposes.

\subsection{Project inspiration}

This project (see chapters 4 and 5) was inspired by the project LOVA, which was mainly conceived for Primary Education. The novel aspect of the project described in chapters 4 and 5 lies in it being the first time that a project of this kind has been undertaken at the university. But, what is Lova? The Opera, a Learning Vehicle, basically aims to turn the classroom into an opera company. As Sarmiento (2012a:40) indicates: "LOVA uses the metaphorical and evocative power of the performing arts, teamwork and overcoming challenges as a platform to develop identity $[\ldots] . »$

The Lova project emerged in Spain thanks to the American professor Mary Ruth McGinn who, in 2006, adapted the Creating Original Opera Project in Madrid. Briefly, it is intended to convert elementary classrooms into an opera company and to offer a performance at the end of the academic year. The project «[i]ntegrates learning from different areas (language, physical education, mathematics, art, music, etc.) for personal development through empowerment as its main goal [...]» (Sarmiento, 2012a:41). Therefore, it was considered proper to devote chapter 3 to exclusively deal with interdisciplinary work.

It is worth highlighting one novel aspect of the LOVA project that other similar projects do not contain, which is that «everything is decided, created and managed by children: the script, lighting, set design, company name and logo, acting, advertising, purchasing of materials, music and its instrumental execution, costumes, make-up, props, stage management, budget management, tasks allocation, etc.» (Sarmiento, 2012a:41). Therefore, one of the most characteristic features of this form of work is that «[...] it allows something much more important than merely combining subject matters: students' autonomy» (Sarmiento 2012b:33). 


\subsection{Musical theatre production for educational purposes}

Musical theatre production aspects are essential to obtain satisfying experience. By means of a literature review, themes emerge around scene roles and creative features (Miller, 2000). First of all, students must know the characteristics and tasks of each role. Thus, students can choose a role with more awareness from the very beginning.

The most important role, which is potentially not appreciated in the musical theatre, is the producer. As Novak (1988) states, a musical theatre consists of only roles with words and music until a producer forms an opinion of the programme, and then the process of transforming the words and music into a production commences. Therefore, the producer is responsible for ensuring that all roles work (Engel, 1983). Interdisciplinary planning mixed with humble commitment capacity (Oneglia, 1973) are essential tools for a producer.

One of the producer's tasks is to assign adequate roles to group members. Laster (2001) backs creating an art production team and production personnel. The ideal arrangement for a musical theatre production would involve a team with: an artistic director, music director, choreographer, people involved with the technical side of the production, set designer, lighting designer, costume designer and sound engineer. Other roles that could be included, as Williams (2003) states, are a vocal director, stage manager, advertising staff, marketing staff, design staff and programme sponsorship. Once the producer has formed his team, the art team works on the cast: orchestra, rehearsals pianist and director of the dance troupe. The head technician is also an important role which oversees that the technical team is working (scene painters, seamstresses, etc.).

The musical theatre as an educational tool at the university has been scarcely used. Therefore, it is convenient to take similar experiences acquired in Primary and Secondary Education as educational models. According to Laster (2001), in Primary and Secondary Education, most of the production tasks correspond to the teacher. At the university, and within the musical theatre creation process, the teacher becomes a facilitator. Therefore, the spokesperson of each group will carry out the producerspokesperson tasks. This role should be temporary so that the same person does not always shoulder the responsibility. The producer-spokesperson should: (1) define the production objectives; (2) present productions with educational value; (3) plan and encourage participation; (4) ensure that musical activities are maintained from an appropriate perspective within the educational programme; (5) promote cooperation between musical activities and other learning areas; (6) encourage persons with or without experience in performing arts to participate; (7) help production to be the result of cooperative effort (Fields, 1970).

The group's producer-spokesperson is particularly important to acquire a good educational outcome through the musical theatre. Poor organisation could cause many problems for group members (Filichia, 1997). Sometimes, the creative 
teams' naiveity of available repertoires is a factor that leads to poorly select a show (Lucha-Burns, 1986). This is where the continuous monitoring of teacherfacilitators becomes specially relevant. Choosing the right programme is no science, but certain aspects must be taken into account, such as: company members' skills and who the musical theatre addresses (Engel, 1966). Moreover, dialogue among groups is highly relevant in order to decide what and how to address the repertoire (Laster 2001; Burnau, 1966). A well-arranged musical theatre will make the job much easier for everyone involved (Janicki, 1982).

First, it is necessary to choose the theme to work on. Then, the short- and longterm goals are set. The technical team is in charge of breathing life into stories based on creativity and innovation. The process will be supervised by the technical director, and both the technical director and the technical team are responsible for providing the script, lighting, sound, and other elements that help understand the general idea of the work (Engel, 1983). Therefore, developing a storyboard to help provide a general understanding of the work, which is divided into acts and scenes, is recommended (see table 1).

\begin{tabular}{|c|c|c|c|c|c|c|c|c|}
\hline \multicolumn{9}{|c|}{ ACT I } \\
\hline Scene & Characters & Costumes & Music & Lights & Props & Projection & Dialogues & Storyboard \\
\hline I. Banker & $\begin{array}{l}\text { Antonio } \\
\text { comes on the } \\
\text { scene from } \\
\text { the side }\end{array}$ & Suit and tie & $\begin{array}{l}\text { Without } \\
\text { music }\end{array}$ & $\begin{array}{l}\text { Lighting } \\
\text { off }\end{array}$ & $\begin{array}{c}\text { Torch in } \\
\text { hand }\end{array}$ & $\begin{array}{l}\text { Without } \\
\text { projection }\end{array}$ & & \\
\hline
\end{tabular}

Table 1. Technical Script

It should be noted that all the roles in the musical theatre are equally important both on and off the stage, although those behind the scenes sometimes go unappreciated (Engel, 1983), and if their work is poor, the quality of the production is markedly affected. The roles behind the scenes are the reason why the main characters can properly channel all their efforts. Nevertheless, it is recommended to work cooperatively; that is, the company should perform all roles in one way or another. If we begin from a specialised role or task, we can tackle all the other complementary tasks. 


\subsection{Some musical theatre roles for educational purposes}

\section{- Director-teacher and student-musical director}

Before work starts, it is worth organising discussions of all kinds. This helps avoid to misunderstandings when allocating roles (Trytten, 1988). Group members must know as many roles as possible. According to Janicki (1982), the role of the director (witch has to be temporary) should: (1) select a suitable production, (2) select roles, (3) behave properly during rehearsals, (4) make a set of available materials, (5) suggest costumes and make-up, (6) use basic lighting techniques, and (7) create confidence and enthusiasm in the group.

The director's main responsibility is to work with the company as a whole, while the music director heads the musical areas (Boland and Argentini, 1997). Directors have more responsibility during rehearsals (Boyes, 2003). It is at that point when most of the learning takes place (Grote, 1986). Thus, those directors who overlook the process and only value the final product, deprive students of valuable educational experience. The process for performing an educational musical offers students the chance to go beyond their limits (Lee, 1983). As Sarmiento states (2012: 43):

\footnotetext{
Not understanding the difference between educational processes and products of cultural consumption is a problem for adults, not children. Although we know that the primary goal of education is not the creation of consumer culture, we tend to judge stubbornly educational process products like consumer products, but the goal of the students is to learn, not to create films, works of theatre, circus, concerts, exhibitions, etc.
}

The music director's role must set the pace of rehearsals and, ideally, must have knowledge of the piano (Laster, 2001). The roles of the director, musical director and choreographer make up the creative forces in the musical theatre experience and their leadership skills (Hoare, 1993). On the day of the premiere, the director's role does not involve that much, unlike the music director's role, which involves supervising the music part (Engel, 1983).

\section{- Singing, dancing and acting}

Interpreters play the most visible roles in the musical theatre. They must sing, dance and perform drama; most have been better trained in one discipline than in another (Janicki, 1982). They are enthusiastic (Boland and Argentini, 1997), and they transport viewers from incredulity to credulity.

Balog (2005) speculates on the misunderstanding between the technique used to sing a musical theatre and classical singing. Alt (2004) adds that training programmes in conservatories do not prepare students to learn by heart. One general objective that is expected of them is a well-produced tone (Catania, 2004), but according to Boardman (1987), the technique considers the following recommendations: 
(1) the musical theatre singer must have an open, pleasant voice; (2) the voice must be easily produced, count on the support of the diaphragm and be driven by abdominal muscles. In other words, the singer must lead a healthy life and use a technique based on breathing.

The triple responsibility of dance, interpretation of movements and the choreographer's gestures are necessary to develop a musical drama (Sagolla, 1992). The success of the dancing artist depends heavily on choreography creativity and musicality. The choreographer invents his/her work from signals in the script, as do the technical designers. Thus, the sources for choreographic material stem from the script and score, and each choreographer attributes movements of the musical theatre which provide clarity to the story to be told (Berkson, 1990). 
CHAPTER 4

\title{
Pilot project and collaborative learning
}

\author{
4.1. Introduction \\ 4.2. Project background \\ 4.3. Phase I: pilot project \\ 4.4. Phase II: Group 1 collaborative project
}




\subsection{Introduction}

Chapter 4 is an overview of the project background. For this purpose, the work has been divided into three phases or periods which refer to each academic year in which the project took place. Then, all the details of the project phases, both the pilot project and that on which the collaborative project has been based, are discussed.

\subsection{Project background}

This project has been shaped according to three main phases or periods:

- Phase I (pilot): planning and designing the project. This was achieved through a first pilot project with students studying year 2 of the Music Education degree as part of the Instrumental Groups I course of the 2nd semester of the academic year 2008/2009 at the Castilla La-Mancha University (Albacete Campus).

- Phase II: the musical theatre educational programme was implemented by a collaborative learning methodology. This experience took place at the Universitat Jaume I of Castellón, with students of year 2 of the Music Education degree as part of the Musical Pedagogy practicals of the 2nd semester of the academic year 2010/2011. During the first classes, the project was presented to the students, who were enthusiastic and willing to participate. During the 2-hour classes, both practicals groups (PR1 and PR2) became two musical theatre companies with their areas and departments. To implement this, individual roles were divided as follows: (1) on stage: players of musical instruments, singers, dancers, actors, etc.; (2) off stage: tailors, set designers, hairdressers, etc. After this distribution, all the students chose three roles in order of preference. Later, the educator distributed the different musical theatre tasks as fairly as possible. One of the drawbacks of this methodology is that some roles involve more workload than others. Therefore, it is advisable to define well the tasks of each role to be played from the very beginning.

- Phase III: a cooperative learning model was taken as a starting point by considering the improvements proposed by students of the previous academic year. The experience took place at the Universitat Jaume I during the 2nd semester of academic year 2011/2012 with Musical Education degree students and with students from other Education degrees. A new feature was to introduce multiple roles (on and off stage) and to define precisely the tasks involved in each one. The number of educational subject matters involved in the project also increased (5 optional, 2 compulsory). Likewise, an information seminar was held with the educators involved in the project whose aim was, on the one hand, (1) to work the interdisciplinary part with 
cooperative learning and, on the other, (2) to perform a single task, but one of better quality, which could be evaluated simultaneously for several subject matters. Another novel aspect was to organise group tutorings. This was done to guide each group during the building process of their project (see chapter 5), and the advantages and disadvantages of using group tutoring as a teaching strategy were considered, as outlined by Pino Juste and Soto Carballo (2010).

\subsection{Phase I: pilot project}

In relation to the previous point, another novel aspect was added to the project design, that of students pursuing a defined and achievable goal. In the specific case of the pilot project, this took place by means of a final performance of the work on 12 May 2009 at 20:00h in the Albacete Campus Auditorium. ${ }^{1}$ Figure 2 shows one moment of the final performance and the TVE2 video shows a summary of it. ${ }^{2}$

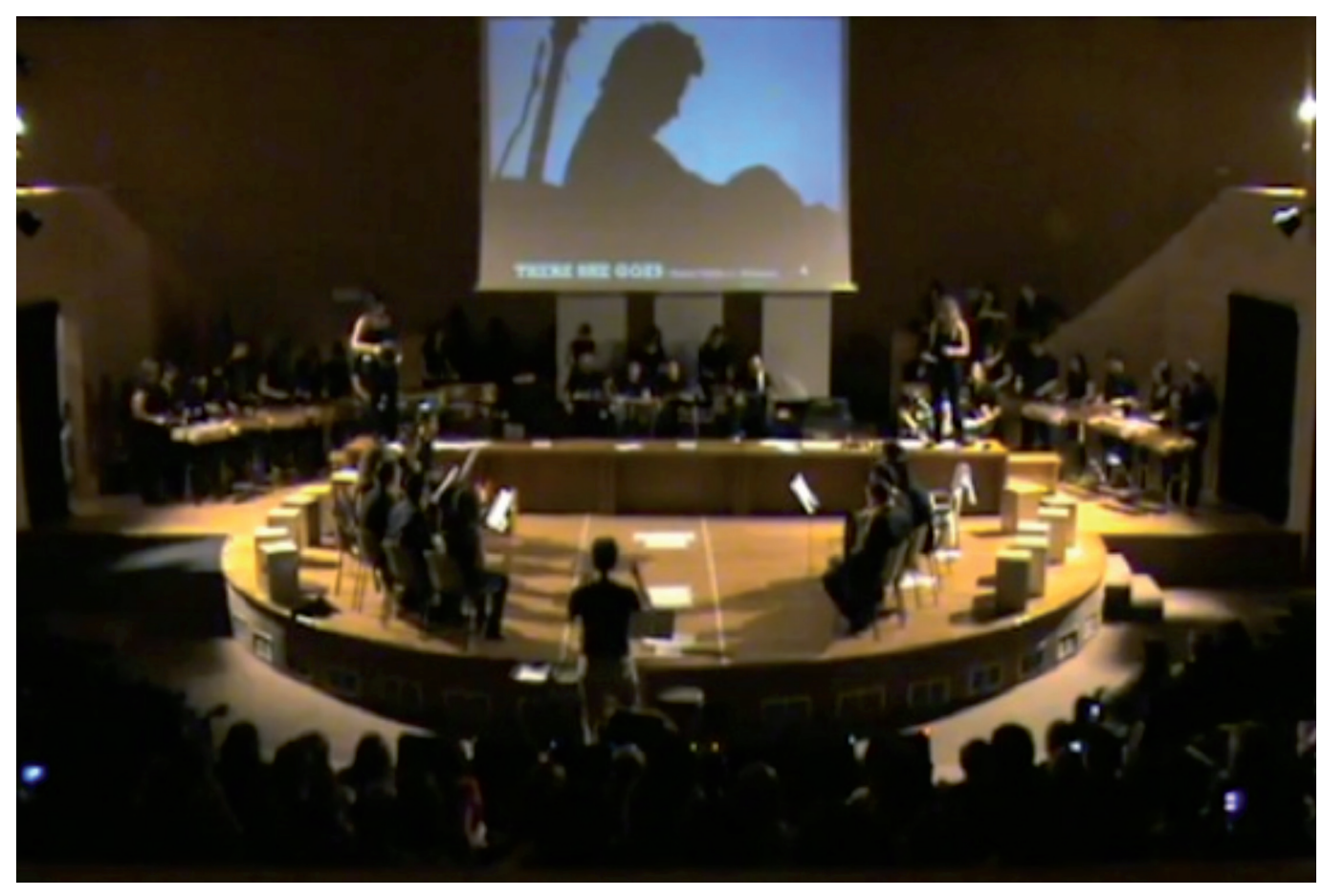

Figure 2. Final concert of the pilot project

It is noteworthy that the responsibility of the pilot project was shouldered more by the teacher than by the students. Therefore, students' range of creativity and autonomy was much more limited than in Phases II and III (see the summary of figure 3).

1. The last piece performed http://goo.gl/SI0Qp.

2. http://goo.gl/gvo92. 


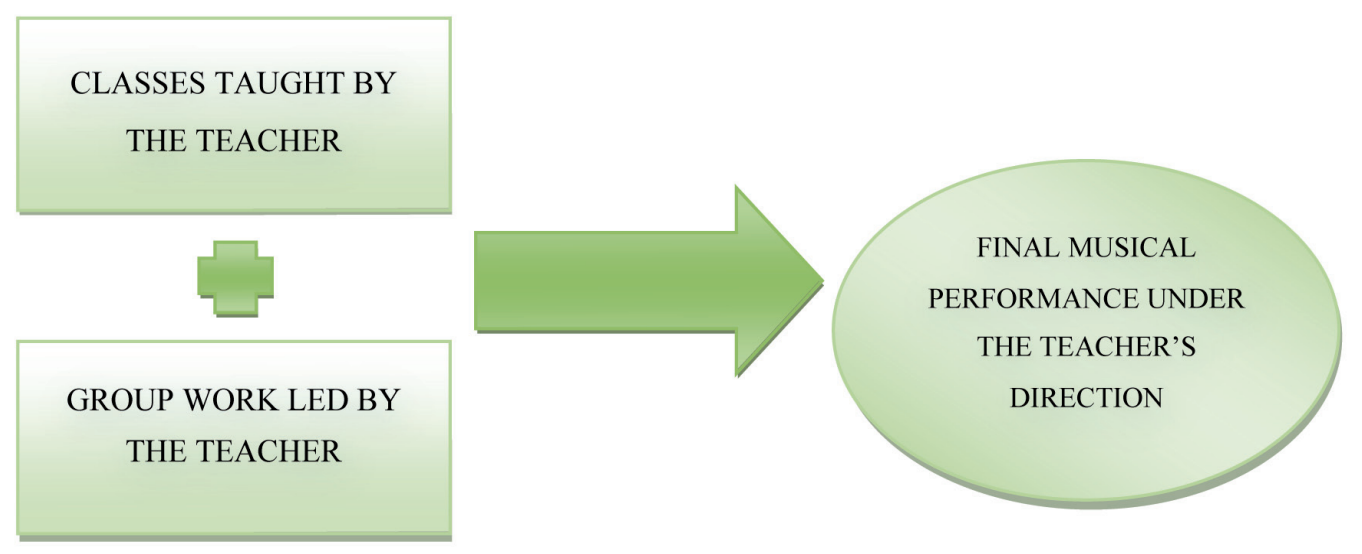

Figure 3. Summary of the pilot project

\subsection{Phase II: Group 1 collaborative project}

Phase II was constructed from the previous phase and was inspired by the LOVA project (see Sarmiento, 2011a). Thus, a collaborative methodology was used and designed to work in the two groups (PR1 and PR2) with the final performance divided into three acts. The practicals class group was divided into two subgroups (PR1 and PR2), where each subgroup created its own musical theatre. Within each subgroup, the roles were distributed to form six departments, as shown in figure 5 . The first theatre was led by PR 1 , the second theatre was conducted by PR 2 , while the third and last performance was the sum of both groups along with the participants in a workshop called Creating a Musical Spectacle held some days before the performance held at the UJI

Those participating in this Phase II were the students studing year 2 of the Music Education degree during the academic year 2010/2011 at the Universitat Jaume I (UJI) of Castellón. During the 2-hour attendance and non-attendance classes of the 2nd semester, and within the practicals framework of the Musical Pedagogy subject matter, the class became a musical theatre company.

Two of the three acts were completely performed (scripts, musical arrangements, etc.) by each group (PR1 and PR2). The third and final act was composed of the practical activities proposed in class by the teacher, which varied depending on and improved by students. As previously mentioned, the last act was the sum of both groups (PR1 and PR2) with the participants of a workshop called Creating a Musical Spectacle. The course was given by a dancer from the National Dance Company, who focused on improving each group's aspects, such as: choreography, lighting, costumes, etc. The final performance took place on 26 May 2011 at 20:30h in the Assembly Hall of the Faculty of Law at the UJI. ${ }^{3}$

3. A promotional video was done by the Communication Department of one of the companies on http://goo.gl/etymK). 
Figure 4 shows the summary of the Phase II methodology of the project based on a collaborative work model.

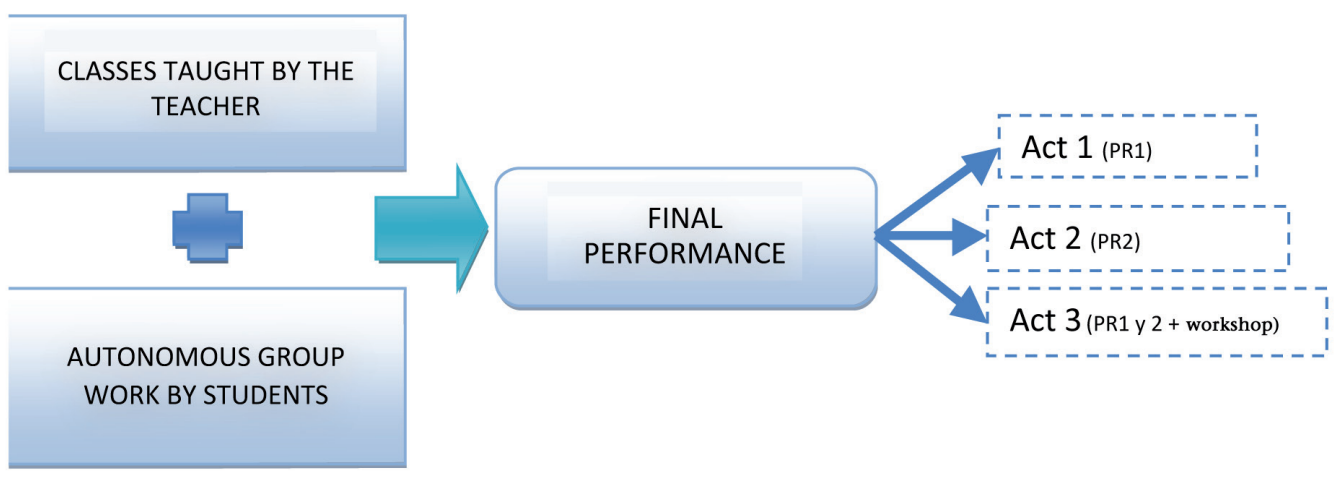

Figure 4. Summary of the collaborative project: Group 1

The classes led by the teacher were conducted in parallel with the students' autonomous work. The first hour of class was dedicated to the practical activities proposed by the teacher, while the second hour was spent sharing the work done by each department. The responsibility fell mainly on students who had to coordinate themselves autonomously. The teacher's role was to guide students to achieve their goals. Below there is a brief description of the process used to develop the project.

The first week of the 2nd semester activities was spent introducing the Musical Expression Pedagogy subject matter. In the same class, the collaborative project was presented to students, who all gladly accepted it. Thus, each subgroup became a company where students chose three roles in order of preference. Later, the teacher assigned a role to all the students according to their preferences and sought subgroup homogeneity (see table 2). Over the remaining 12 weeks, project work was done, which culminated in a final public performance.

ON STAGE

Image and sound

Interpreters

Technical support

Singers

Dancers 
Actors and actresses

\section{OFF STAGE}

Graphic designers and publicists

Comunication

Customers

Set designers and props

Screenwriters

Composers

Hair and make-up

Portfolio editors

Pedagogic department

D1

D2

D3

D4

D5

D6

Table 2. Distribution of the roles in the collaborative project

Every department prepared the specific tasks required weekly for the next class session (for example, see table 3).

D1

- Image and sound: Resources to be used to record staging and later editions (video art, animation, etc.)

- Interpreters/technical support: To bring the musical instrument and to show a battery of the technical resources that can be used with it.

Table 3. Example of the roles in the collaborative project

During the last week of the course, the qualitative and quantitative data were collected with the aim to deal with the strong and weak points of the project. The main weak point stated by students was lack of time. One student stated: «12 sessions are not enough to finish a project like this». The proposed solution 
would have been to use one complete academic year, and not just the 2nd semester. Students felt that there was too much work for a single performance to obtain $33 \%$ of the final subject grade with 8 credits. Another weak point was, as students mentioned, their excessive autonomy. They wanted, on the one hand, more concise guidelines on the project and, on the other, more teacher intervention in the problems that each subgroup raised. Coordination among students was something they said they were not used to. Nevertheless, collaborative work generally caused a positive impression on students.

Figure 5 illustrates the first musical theatre on the day of the performance, which lasted approximately 30 minutes. The first company (PR2) was presented under the title: The latest show. The musical drama told the story of an old theatre forced to close due to poor public attendance. The story served as a pretext to look back and to review all the stars who were on stage in their glory years. Thus, different styles and epochs were presented in a single proposal. The performance was filled with other parallel activities run by the educational department of the company as if they were telling a story.

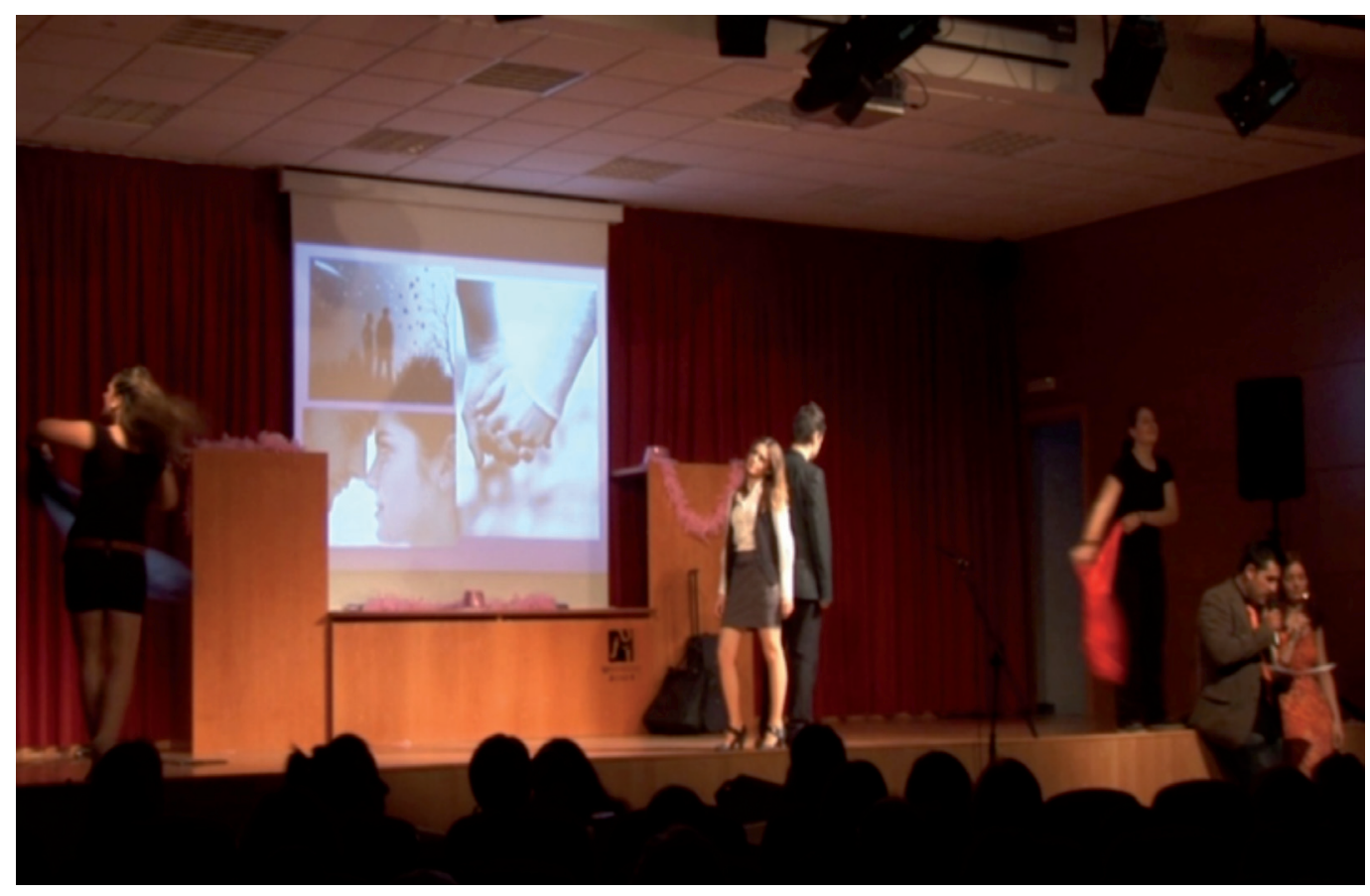

Figure 5. First performance by group PR2

Figure 6 shows the second company (PR1): Feel the difference!, which performed a work that transported viewers to the year 3000 where the world had taken on absolute monotony. Society as a whole followed the same fashion, listened to the same music and was mastered by the same terrible evil (the main character of the musical), the Ga-Ga society. Its opponent was a group of bohemians living in the catacombs of the city that did not follow the same current as everyone else, but took life at their own pace and did not surrender to the masses. This group of bohemians dreamed with melodies from ancient 
times in which variety was the order of the day. In the thread of this story, there was a love relationship between Amadeo and K422 (the main characters of the story) belonging to different social groups. Together they revolutionise the world with their ideals.

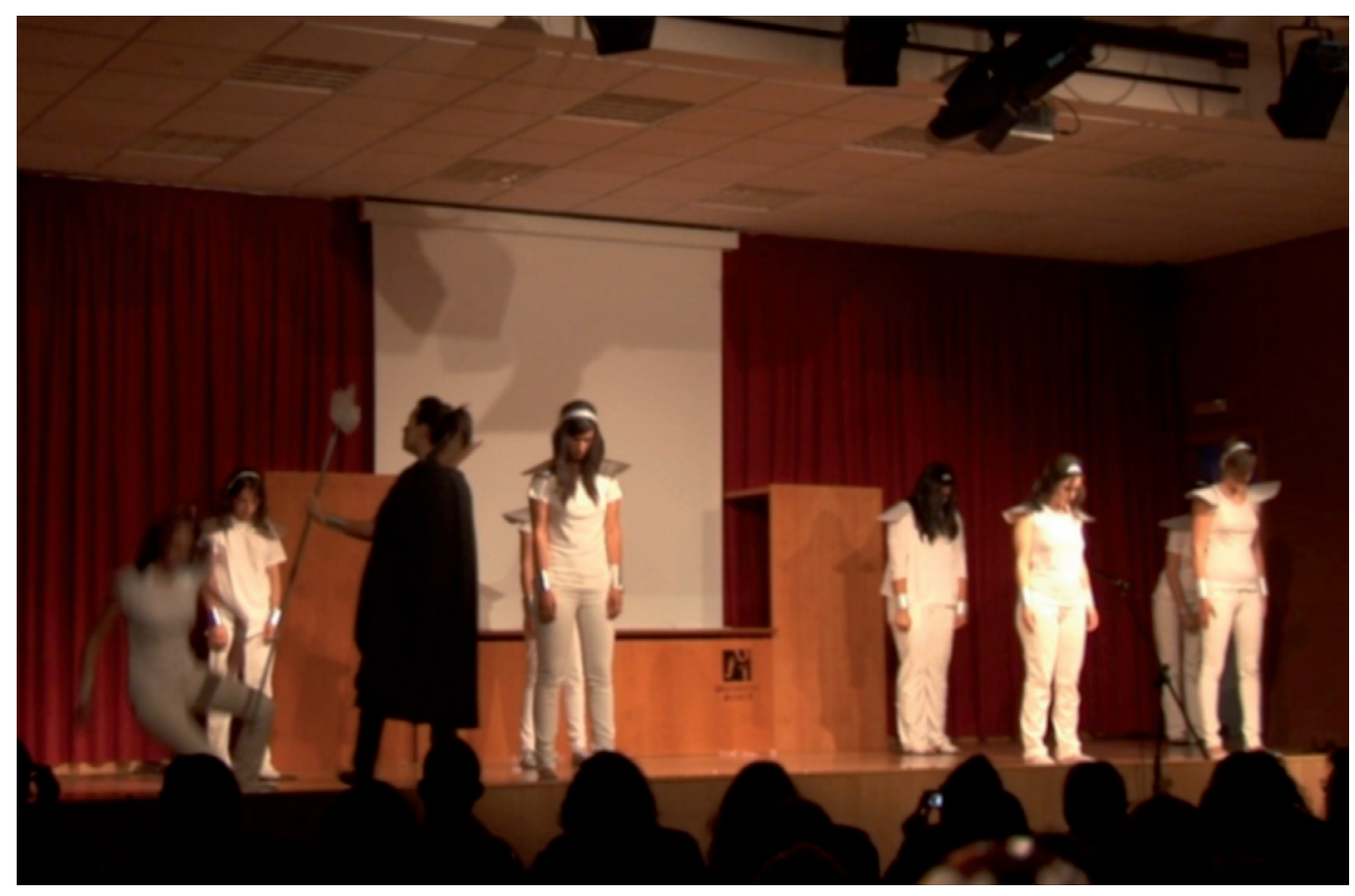

Figure 6. Second performance by group PR1

Finally, figure 7 shows part 3 of the musical theatre where all the students from both subgroups participated together with some participants from the Creation of a Musical Spectacle course. The last act was presented to the public as a «music class» in a musical theatre format. The intention was for students to practically and concisely present the public with a music class by simulating the reality of a classroom as much as possible. ${ }^{4}$

4. Web created by the Communications Department at: http://elultimoespectaculo.wordpress.com and in Facebook at http:// goo.gl/0QnQM). 


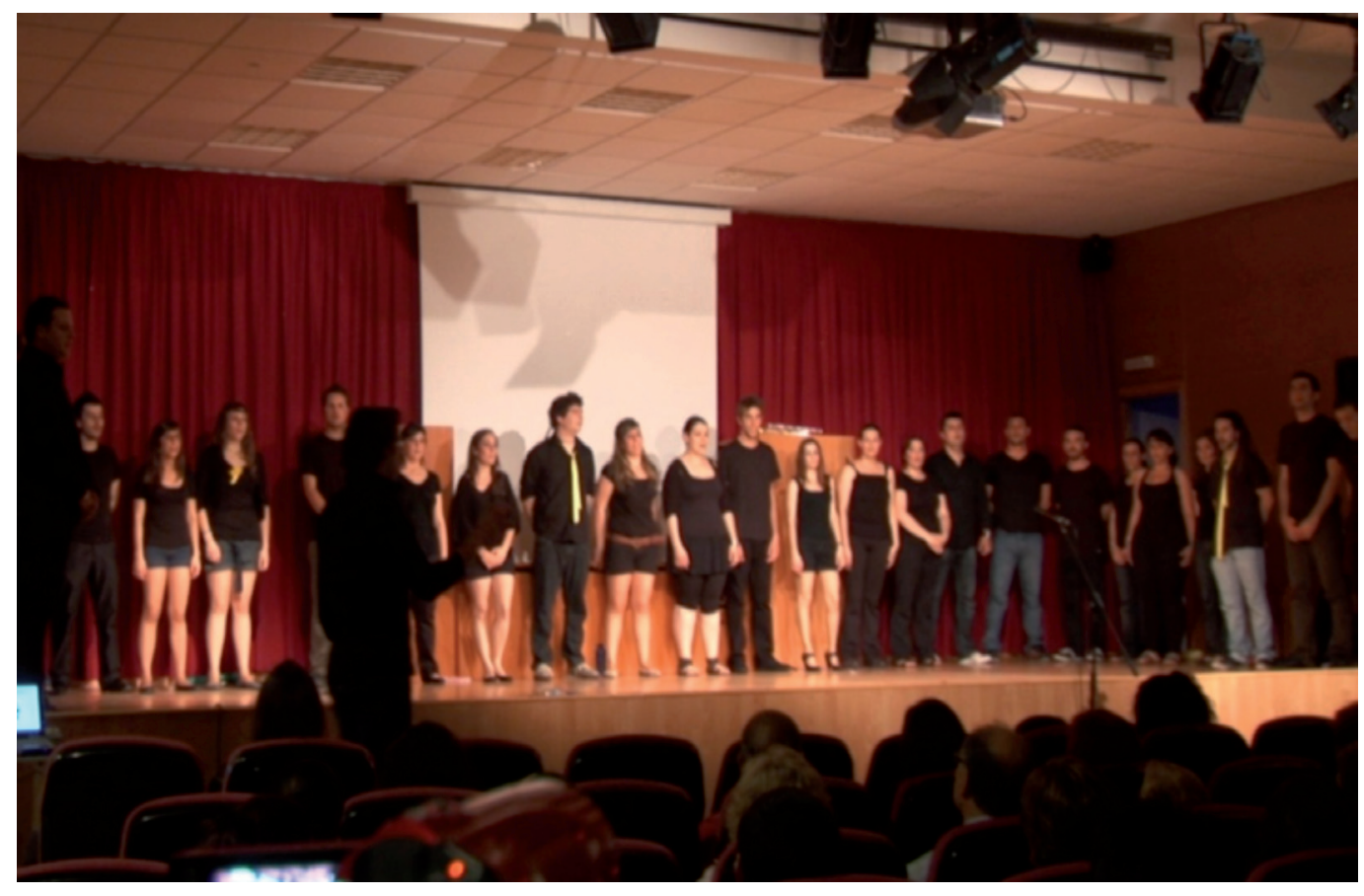

Figure 7. Third performance of all students together 


\section{CHAPTER 5}

\section{Cooperative learning}

5.1. Introduction

5.2. Phase III: cooperative project

5.3. Development of the cooperative project

5.4. Evaluation of the cooperative project

5.5. Some examples of the cooperative project 


\subsection{Introduction}

Chapter 5, the last chapter, provides guidelines for students to undertake projects of this nature. Therefore, the phases conducted in the last project phase are presented; the evolution of former phases. The working model used was cooperative in nature, thus both the development and evaluation models used are described. Lastly, some examples of the cooperative project run during the academic year 2011/2012 are offered. Finally, it should be noted that the project does not end with these three editions, but is still ongoing in order to stimulate continuous improvement with the perspective of encouraging potential teachers to imagine new ways of understanding music education.

\subsection{Phase III: the cooperative project}

Phase III is a continuation of the previous project (see chapter 4) which takes into account its strong and weak points. One of the problems found in the musical theatre project based on a collaborative model is the coordination among all company members (approximately 45 students). This time, the methodology involved cooperatively working in small groups of 5 to 10 students. Various sketches (small musical theatres) were done in an interdisciplinary manner. The time assigned for each group's performance was approximately 1 minute per member. That is, a 5-member group had about 5 minutes to develop their idea. This guaranteed that the duration of all the groups was similar.

For the purpose of this work to act as a guide for future students, a summarised 10-step project is presented, entitled: «Art as an Interdisciplinary Vehicle of Learning»:

1. Contextualise the project. This project started in the academic year 2008/ 2009 (see chapter 4) and was inspired by the Lova project (see section 3.2.), but was undertaken at the university level. The Lova project would be the second specific level, whereas the project presented herein would be the first level. The last -but not the least-important goal was to create a final performance consisting of several sketches, one per working group. Finally, the educator with representatives of each group should provide all the sketches with some cohesion.

2. The format of each sketch. As the primary subject matter was Musical Expression Pedagogy in primary education, the open-class format seemed more appropriate. It helps evaluate students' teaching qualities during a process and in the final performance. It is worth highlighting participants' heterogeneity, which should not necessarily hinder project implementation. Defending an integrated curriculum is especially relevant in this project

The students participating in this project came from various teaching degrees: musical, kindergarten or primary. Thus, the starting point was that 
students could show their pedagogical skills. In the end, the topic had to have an implicit educational content that students should work with explicitly. In summary, students tried to give their classmates a lesson using a sketch lasting a few minutes. But, a lesson about what? (see the next point).

3. The subject matters participating in each sketch. As this is a project with different subject matters within the same studies, such as Primary Teacher Education, the educator presents the participating subject matters throughout the project. By taking into account that not all the students study the same subject matters, the learning contract (see figure 12) indicates the subject matters with which every group member participates. The subjects participating in the cooperative project are shown in figure 8 . But, is it worth justifying the choice of some subject matters and not others? The participation conditions of every subject matter, contents (see the next point) evaluation, etc., should be submitted by all the teachers in their subject matter. For example, in the project done according to the cooperative methodology, some teachers assign subject matters a $50 \%$ of the final grade of the project, while others merely gave an extra mark. Not all students included all the subject matters which participated in the project in the project contract (see figure 12).

4. The minimum content of every sketch. Content was individually assigned by all the teachers involved in the project. For example, in the Teaching of English subject matter, the teacher considered that the minimum content was that $80 \%$ of the text had to be written, spoken or sung in English. Another condition was that every student should perform at least one individual intervention in the sketch. For the Music history and folklore subject matter, the minimum requirement was to use an audition from the folklore programme and the History of Music content (contextualisations, historical sequences, musical encounters among characters, auditions or performances).

5. Group characteristics. Groups should include between 5 and 10 members, and every sketch should last approximately 5-10 minutes. As a guideline, one minute per person was foreseen. That is to say, a group of six students would have around 6 minutes for their performance. Therefore, the students should explain why they chose this group and not another one. For example: "we chose this group because we share many affinities», and also for its individual characteristics and the topic to be dealt with. For instance: «in the group, there is a member who studied piano for 5 years, so we were inspired by the film The piano as the sketch topic».

6. Tutorials and dress rehearsals. It is worth establishing a minimum of compulsory tutoring sessions. The cooperative project included three of the four programmed ones. Each lasted approximately 20 minutes (see section 5.3.). It is noteworthy that reserving each tutorial was carried out virtually by the Google Apps-Calendar computer application. The cooperative project tutorials were carried out in May, 2011. Table 4 shows the schedule. 


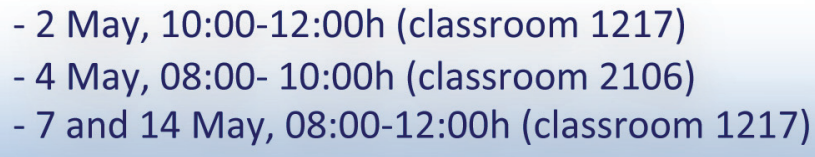

Table 4. Schedule of tutorials

There were two dress rehearsals in the classroom where the performance was to be performed (classroom 2123), on 16 and 18 May from 15:00h to 19:00h, and from 16:00h to 18:00h, respectively. Firstly, the teachers' proposals for improvement were carried out. Secondly, there was a technical performance, which involved simulating the performance as it would be performed a few minutes later. The final performance took place on 18 May at 19:00h pm in the same classroom.

7. Roles. Group members distributed their roles and defined the tasks of each one. Commitment was made by a written contract reflecting the role of each student and the tasks to perform (see figure 12). Distributing roles had two purposes: One was to provide all group members with specific responsibilities, which lead to a more transparent evaluation. The second was to provide creativity and autonomy to all the members; members chose what and how their project was to be. One novelty, as compared to previous editions, was to introduce the idea of multiple roles by combining tasks both on stage (performer, singer, dancer, etc.) and off stage (costume designer, writer, etc.).

8. Minutes. Each group meeting is reflected in a record model (see figure 13). Project information, including the minutes model, was available to students on the first day of class via the Virtual Classroom (see figure 10). The minutes were handed out during each tutorial the group attended. It is convenient to add each group member's individual work to the minutes as an appendix. For example, if a group member does a YouTube search for different versions of a particular song, his/her search process should be reflected, as should the keywords used, the number of entries found and, finally, why a video was selected and not another one. It is worth noting if, for example, search words are very general ones and if many entries were found. For example, if we write the word «Worksongs» on YouTube, we obtain approximately 15,700 results. Yet, if we limit the search to descriptors, e.g. «Worksong in Africa», we find 86 results. Note that the number of results constantly changes.

9. Communication among groups. This project stage is designed for those seeking to improve their grades. The idea is to request volunteers to comprehensively work in communication and marketing tasks. These students should take on the responsibility of performing at least one press release, and to advertise and promote the project. This is an additional assignment which 
is assessed within the learning process. With this additional assignment, certain skills are learned, like writing a press release or acquiring skills in ICT: open a YouTube channel to upload the rehearsals, to create web sites, blogs, facebook, etc.

10. Defined and achievable objectives. Specify dates to hand in assignments, for rehearsals, and for the final exam. Project advantages include the possibility of choosing subject matters. Two tutorials should be included at the beginning of the project: the first to hand in the draft; the second to hand in the contract (see Figure 12).

\subsection{Development of the cooperative project}

Six teachers (from the Department of Education) participated in the project. Responsibility was shared between students and teachers. This working model required more preparation and coordination of the teachers involved. Therefore, a few days before starting the 2nd semester, a seminar was held to present and coordinate the project. To carry out the project, the cooperative learning model was followed with seven subject matters from the Education Degree involved, two of which were core subject matters, indicated in green (see figure 8), and 5 were optional ones, indicated in blue (see figure 8).

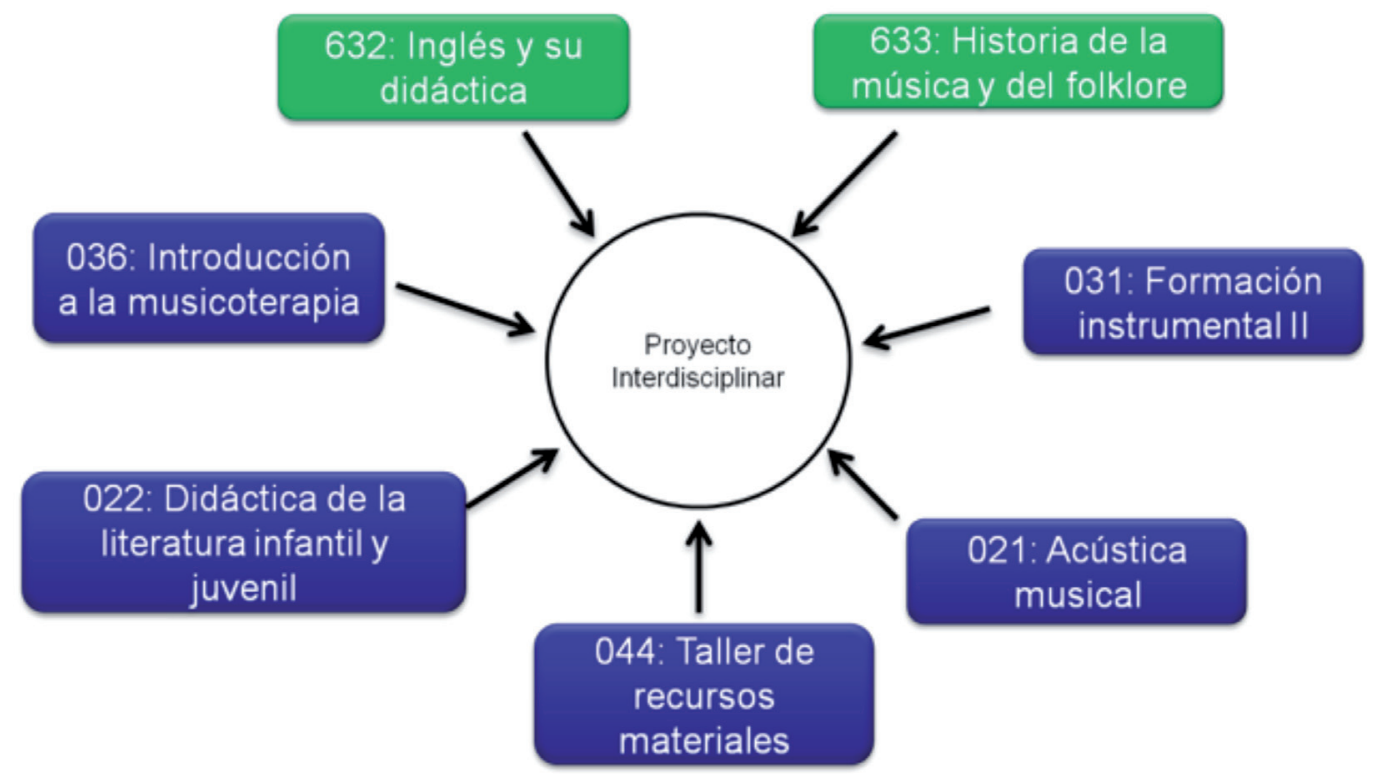

Figure 8 . The subject matters involved in the cooperative project

The teacher's role was to guide and supervise students' work from the beginning to the end. Figure 9 shows a summary of the process followed to develop the project. 


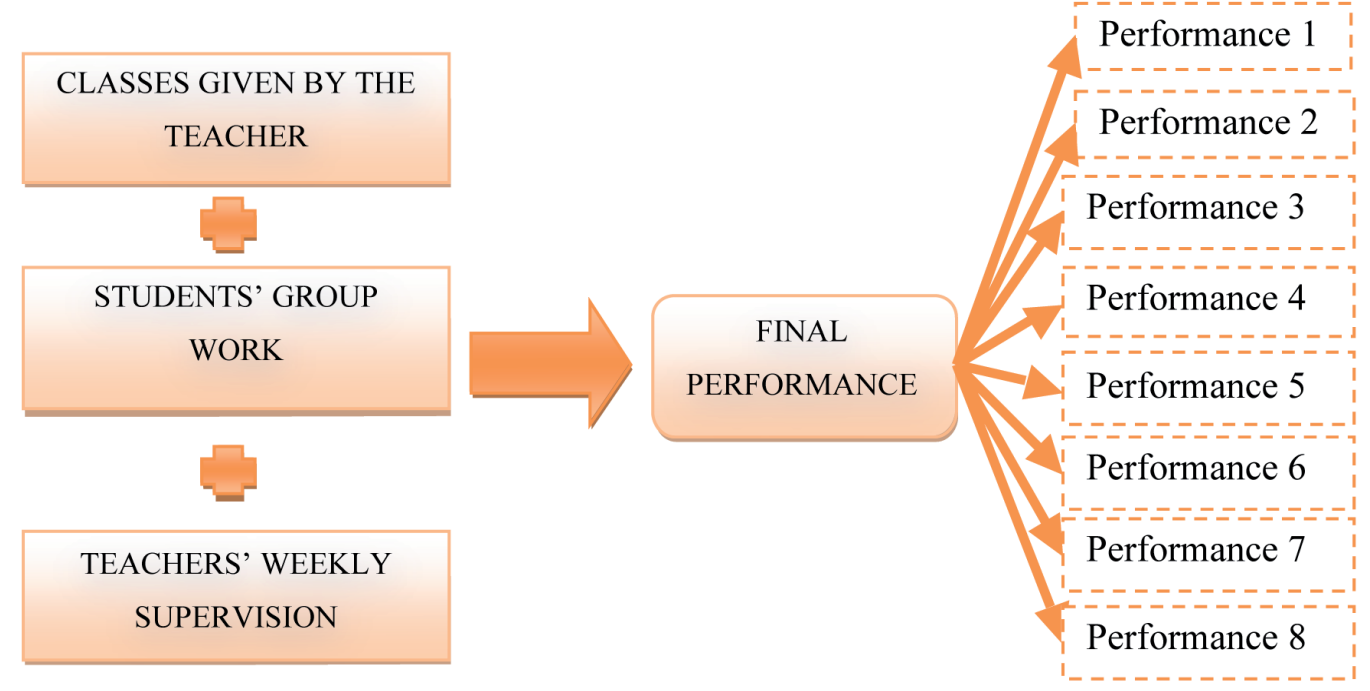

Figure 9. Summary of the cooperative project

The usual contents of each subject matter involved and the musical theatre tools were used as the learning model, e.g. the Virtual Classroom of one of the subject matters involved in the project (see figure 10). This is the Folklore subject matter, which provides details of the contents of the four theoretical sessions available before the project started.

Área personal to Mis cursos $\rightarrow$ c532.20112012
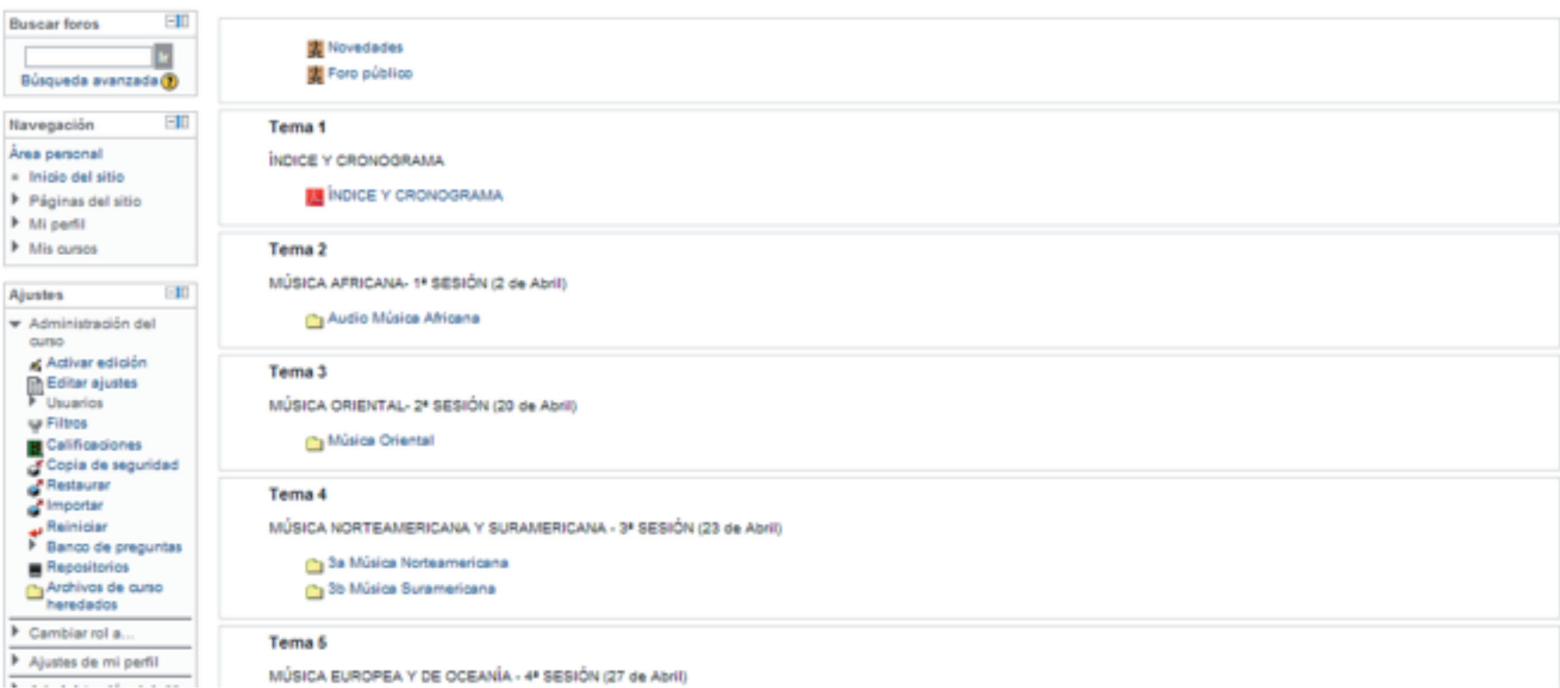

Figure 10. Virtual Class of one of the subject matters involved

Therefore, from the very beginning all the project aspects were available to students, these being: presentation, contract, minutes models, the individual and group rubric follow-up, and the final performance rubric. The intention was for students to know what and how they were to be evaluated at all times (see Figure 11). 
Figure 11. The project documents in the Virtual Classroom

One of the main differences between the collaborative project and the cooperative project was that in the latter, everything was better guided and supervised by teachers; from the project contract (see figure 12), for which two initial meetings were held with every group, to the minutes model (see figure 13), which was handed out at the end of each tutorial. Two initial tutorials were held with the different groups. The objective of the first was that the groups orally present the draft contract, while that of the second was to hand out the project contract.

\section{CONTRATO PROYECTO INTERDISCIPLINAR}

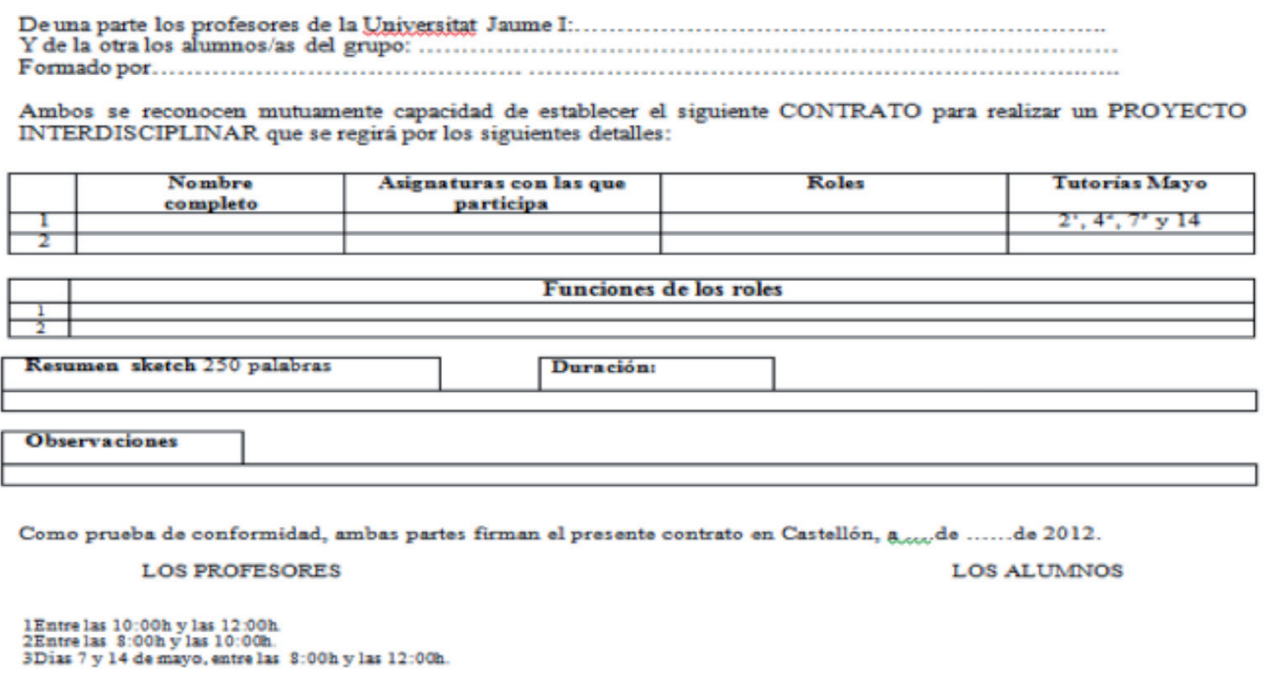

Figure 12. The project contract model

According to previous experience, it was concluded that it would be better to provide students with a minutes model (see figure 13). Minutes were handed out during each tutorial session that the groups attended. Tutorials were carried out with teachers who taught the compulsory subject matters involved in the project. Not all the subject matters had the same level of engagement in terms of content and evaluation. There were subject matters for which teachers decided to offer the chance of voluntary participation. In such cases, participation in the project implied obtaining an additional mark towards the final grade. For example, those students who introduced a guitar into the sketch obtained an additional mark in the Instrumental II subject matter. 
En................. siendo las mon horas del día......de.......de 2012 se reúne el grupo..................(señalar el nombre del grupo) con la asistencia de: ..............................
(señalar el nombre y apellidos de las personas que asisten), con la ausencia justificada de las siguientes personas:................. (nombre y apellidos de los que justifican ausencia) y con la inasistencia de:................(nombre y apellidos de los que no hayan justificado), previa citación realizada y de acuerdo con el siguiente:

Orden del Día

Punto 1:- Lectura y aprobación, en su caso, del acta de la reunión anterior.

Punto 2:

Punto 3:

Desarrollo del Punto 1:

Desarrollo del Punto 2:

(En cada uno de los puntos habrá que indicar la propuesta, que se somete a votación y el resultado de la misma, señalando expresamente si ha quedado o no aprobado el punto).

Siendo las , horas del día señalado en el encabezamiento se levanta la sesión:

Fdo el/a Secretario/a $\quad$ V॰. B Ella Presidente/a.

Figure 13. The minutes model for each session

Each group attended at least three of the four scheduled group tutorials. It was considered that the best way of organising these tutorials was to use the Google Apps-Calendar (see figure 14) because Google Apps is free and does not require any software or hardware. Google Calendar also allows students to make appointments by editing the online calendar quickly and easily. Tutorials for each group lasted 20 minutes. With each reserved tutorial session, confirmation arrived to teachers by email, and the group and time were indicated. For students, the Google Apps-Calendar proved to be an autonomous, easy tool to cancel or exchange schedules among them.

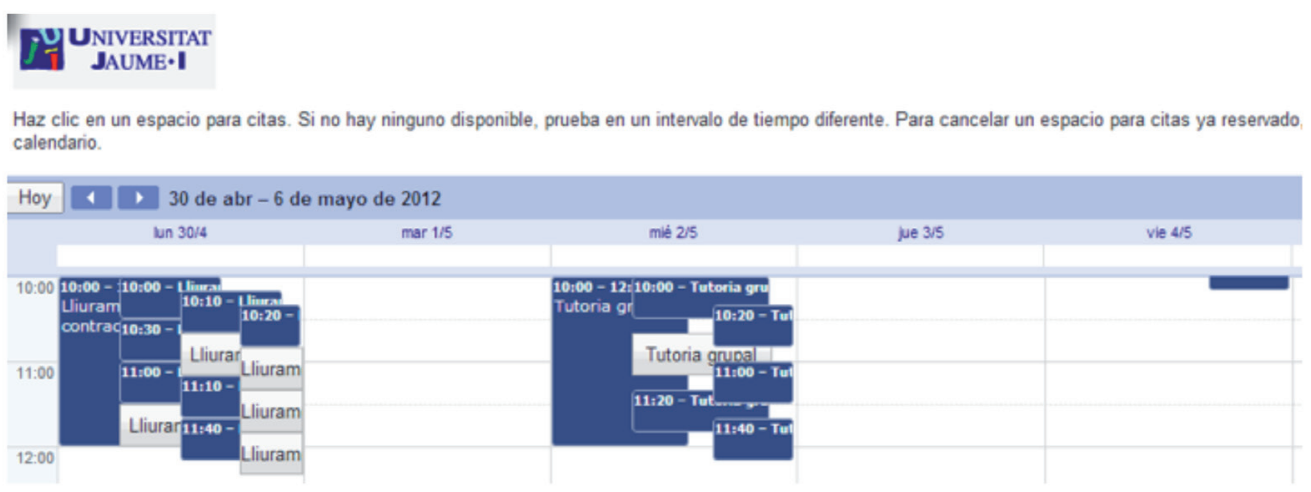

Figure 14. The Google Apps-Calendar 


\subsection{Evaluation of the cooperative project}

Another aspect which improved the collaborative project of the former academic year (see chapter 4) was the design of an individual monitoring rubric. The intention was to highlight the work done outside the classroom in all four tutorials. As previously mentioned, students were supposed to attach individual works to each minutes record. Accordingly, attempts were made as far as possible to show who volunteered to do an assigned task and did it, and who did not. This was done to achieve more equity in the complicated evaluation process (see figure 15).

\section{RÚBRICA DE SEGUIMIENTO INDIVIDUAL-Proyecto Interdisciplinar \\ "El Arte Como Vehículo De Aprendizaje"}

Nombre y Apellidos del Alumno/a:

-Nombre del Grupo:

\section{I}

Día de la Tutoría: $2,4,7$ ó 14 de Mayo.

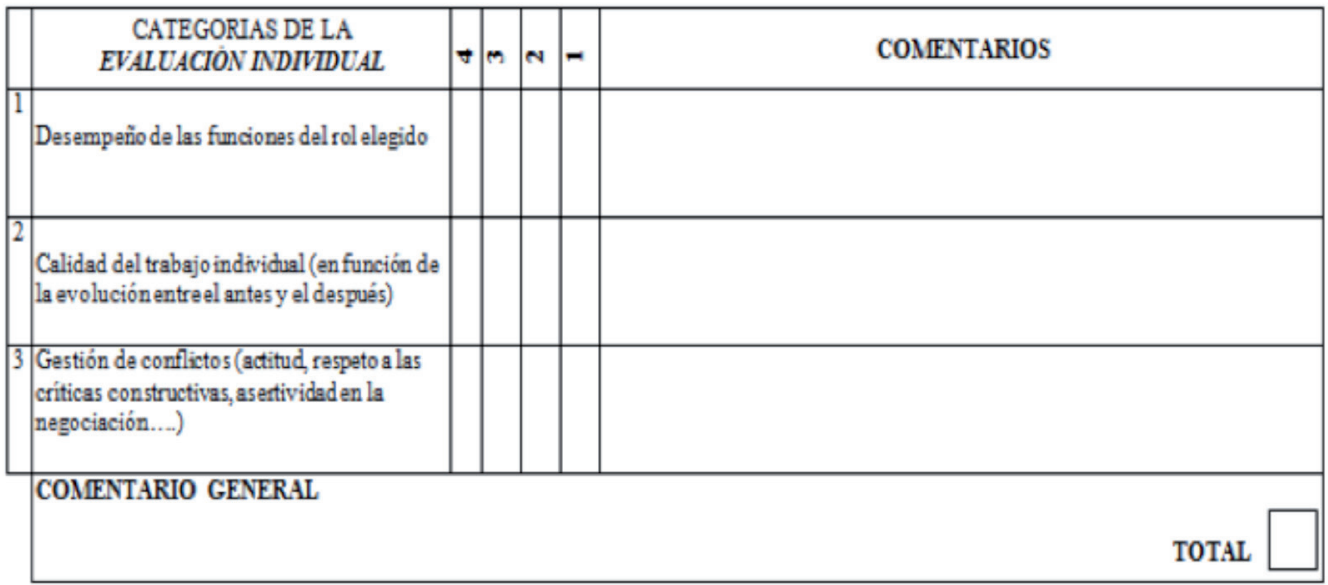

Figure 15. The individual monitoring rubric

Collective work was also evaluated in all the creative phases of the musical theatre. An evaluation rubric of the collective process was created, which allowed us to evaluate different group aspects (see figure 16). As formerly mentioned, each group could voluntarily add those appendices they considered appropriate (minutes of other meetings, videos of rehearsals, etc.). 
RÚBRICA DE SEGUIMIENTO COLECTIVA-Proyecto Interdisciplinar

"El Arte Como Vehículo De Aprendizaje"

-Nombre del Grupo:

-Nombrey Apellidos de los miembros.

Dia de Tutoría: $2,4,7$ ó 14 de Mayo.

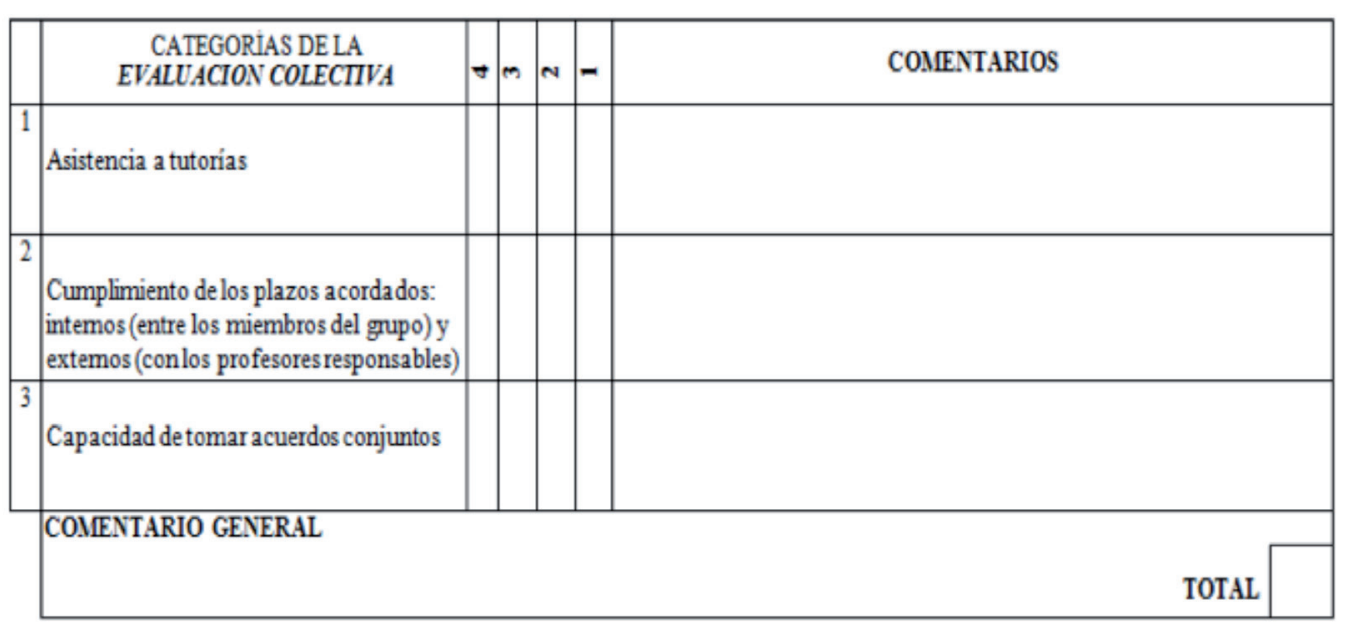

Figure 16. The group monitoring rubric

Finally, there was a section for the final test-performance, which was always held in the music room (see figure 17). Three teachers of different subject matters attended. A copy of the whole performance was given to those teachers who could not attend. Each teacher later individually completed a rubric and common pooling. Collective aspects were considered in the rubric, such as how to integrate content from different subjects or how to interact with the public. In individual evaluations, it was decided to pay attention to the quality of each student's contributions without neglecting any of the comments that each teacher might have introduced into their rubric. 
RÚBRICA ACTUACIÓN 18 de Mayo de 2012 - Proyecto Interdisciplinar "El Arte Como Vehículo De Aprendizaje"

-Nombre del Grupo:

-Nombrey Apellidos de los miembros: 1

2 ..

3.

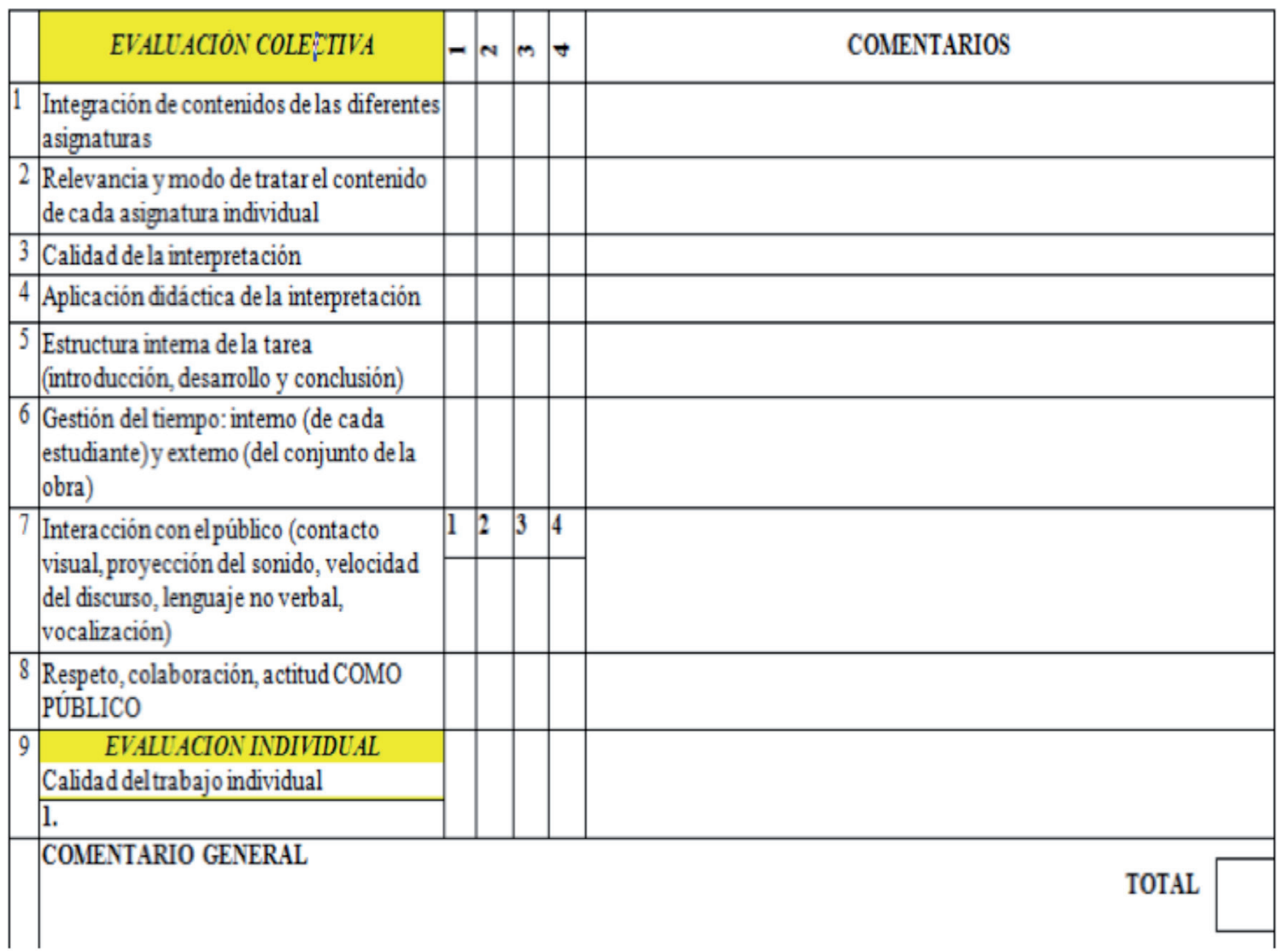

Figure 17. The performance-exam rubric 


\subsection{Some examples of the cooperative project}

The first group was called «The cloud» and had 11 members who performed a musical theatre lasting 12 minutes entitled: The life cycle (see figure 18). In this story, students tried to reproduce the life cycle with two main components: music and dance. Life evolved through a brief look at different pieces of music. Songs were written by the students themselves, and were rooted in Africa, Asia, Europe, and North America. The contents of the Music and Folklore History subject matter were employed. The interaction with the audience, mostly classmates, was achieved using question-answer musical patterns. Noteworthily, most of the script was written in English, therefore students were supervised and guided by the English Pedagogy teacher, who made the necessary phonological and syntactical corrections (see figure 18).

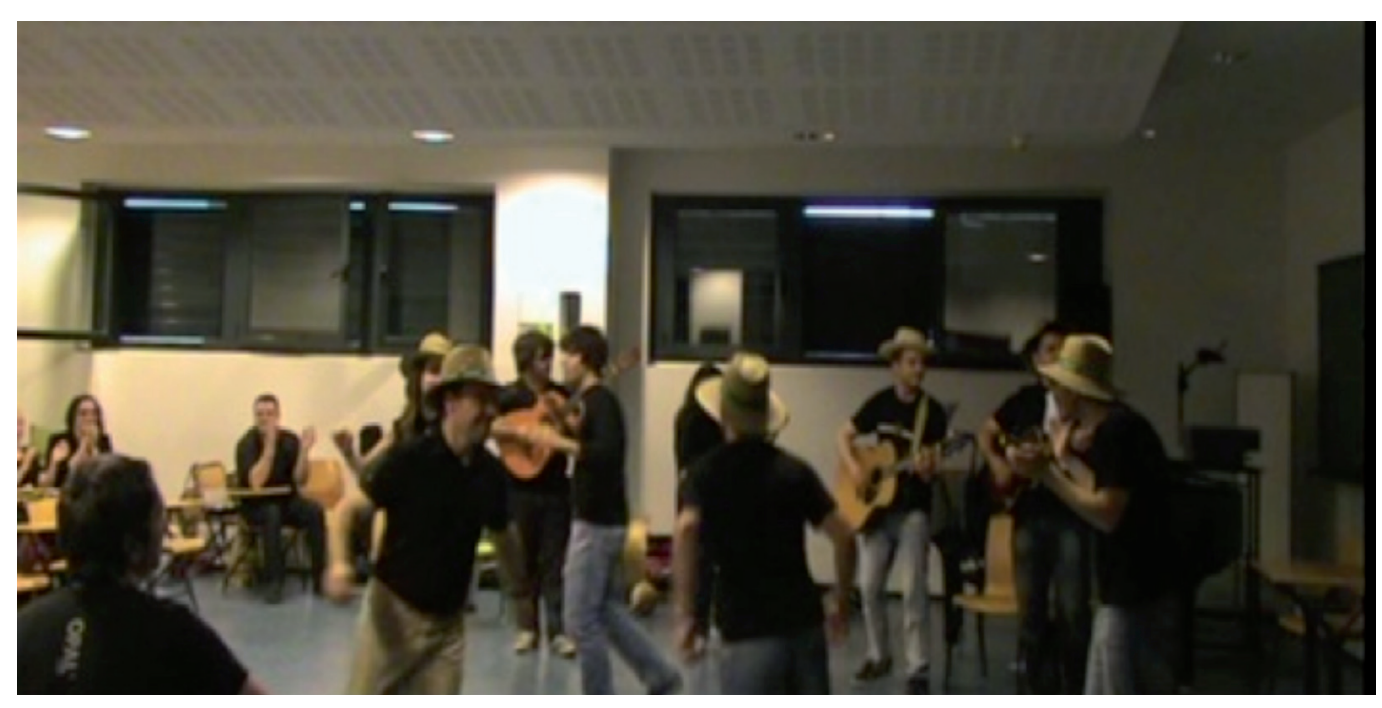

Figure 18. First performance of group 2

The second group, called «Living on the edge», which was composed of seven students, performed a musical theatre called The dream life. The story was based on a real-life event where an old man tells his grandchildren a story about a trip he made around the world when he was young. The performance takes place in the hall of the grandfather's home and, as the story unfolds, the characters recreate the customs and contexts of different places: Africa (Central African Republic), East (China), North America (Canada), ending in South America (Brazil) (see figure 19). 


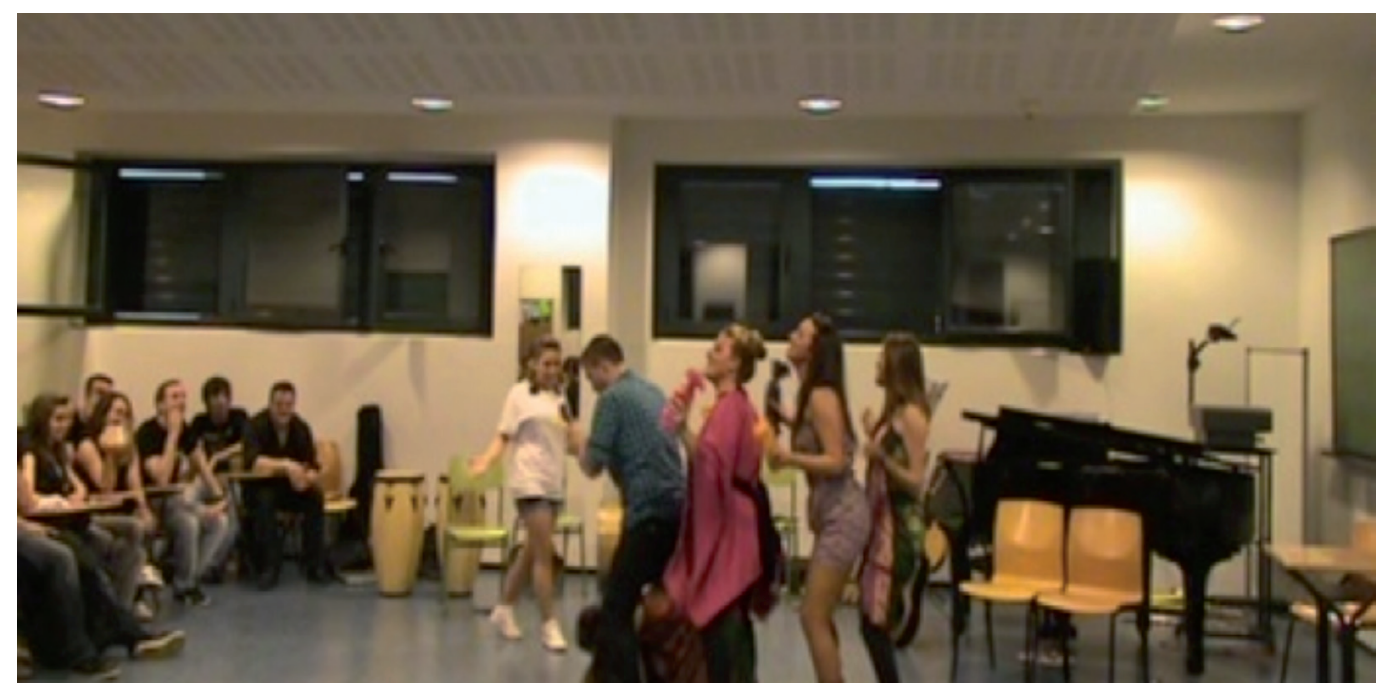

Figure 19. Second performance of group 2

The third group called «The musician's soul», composed of 11 members, was a musical theatre which they called The musician's soul. The story focused on a divorce and how it affects young children. To portray the idea, they took the Introduction to Music Therapy subject matter as the central theme, and it was one that the whole group shared. The work was inspired by the story of Jude, John Lennon's son, who suffered with his parents' separation. The performance was set in the 1960s and 1970s (see figure 20).

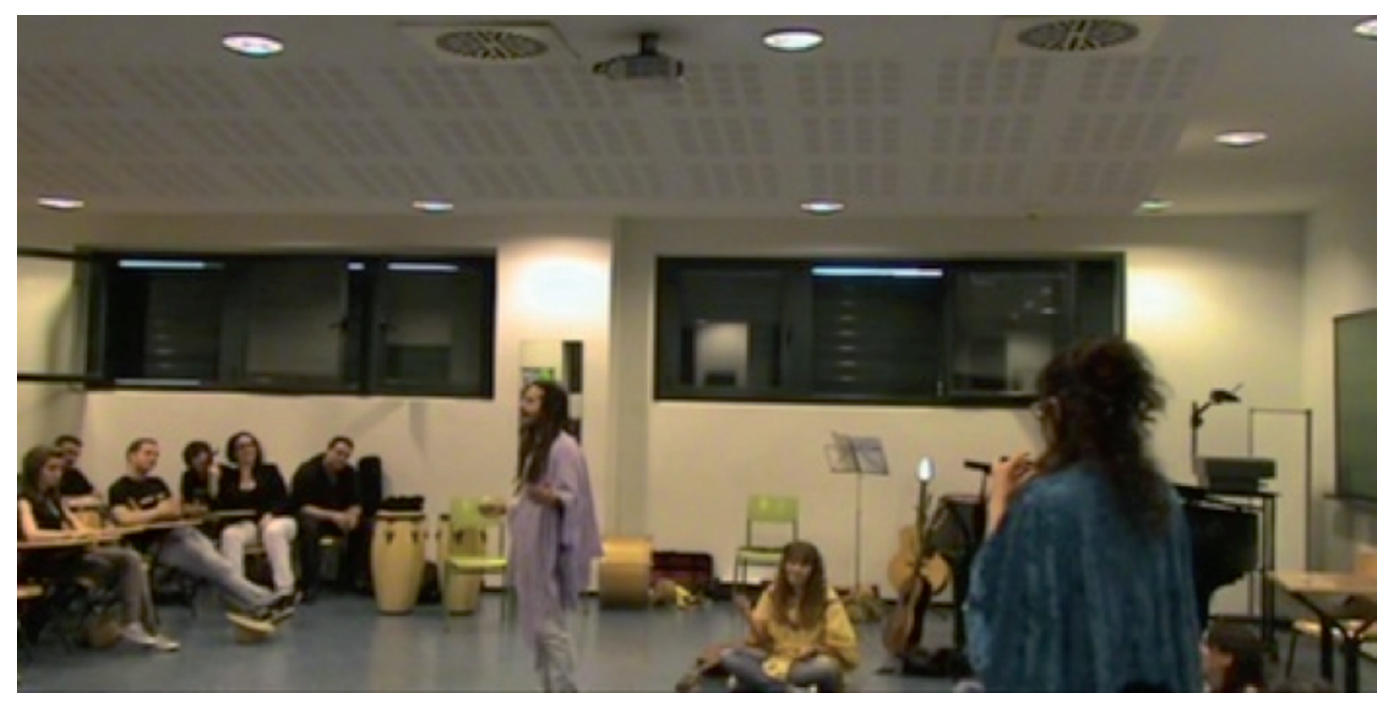

Figure 13. Third performance of group 2

The fourth group, called «Carpe Diem», was composed of 11 members who performed a musical theatre that they called Carpe diem. The goal was to learn to express feelings through the use of music based on a girl with emotional problems and socialisation as the plot. Her teacher notices the problems she has and tries to solve them by using one of the girl's greatest passions: silent films. Through the 
background music of silent films, the intention was to unite two subject matters that were shared by all the members: Introduction to Music Therapy and Musical Acoustics (see figure 21).

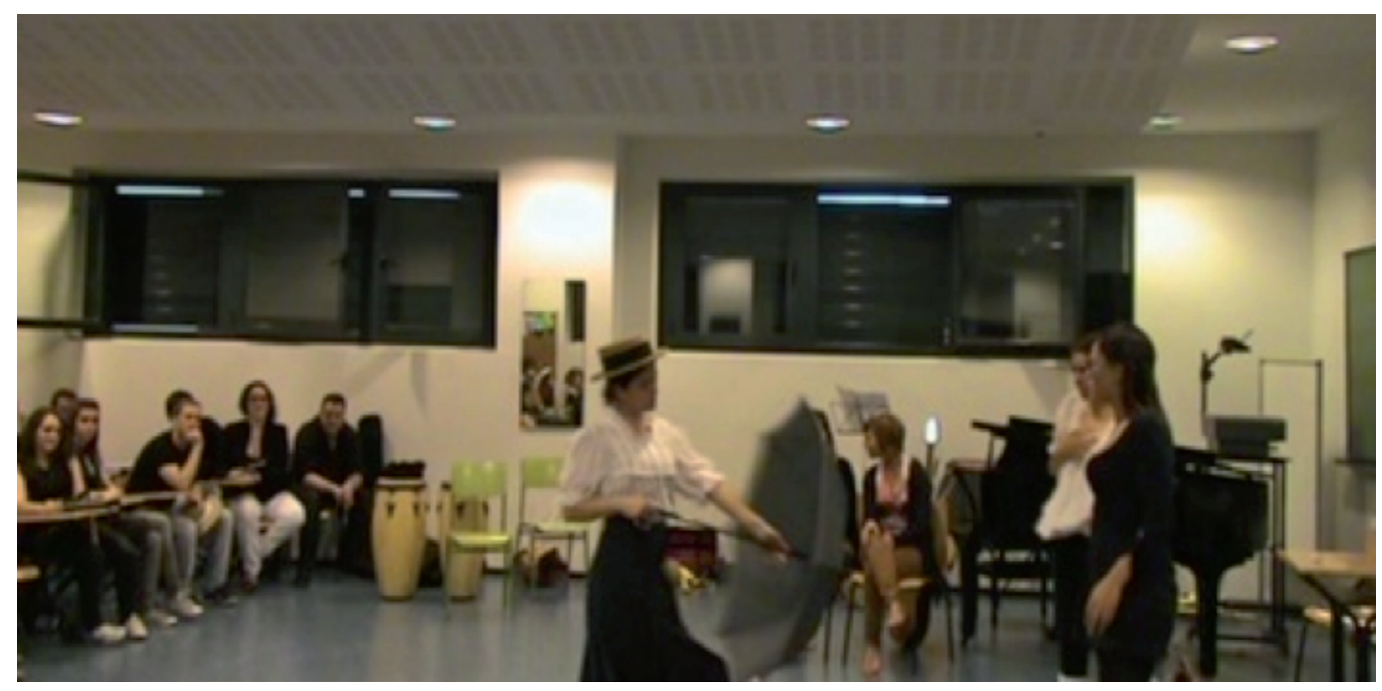

Figure 21. Fourth performance of group 2

The fifth group was called «The Bremen» and composed of 10 members, performed a musical theatre which they called Bremen. The chosen topic was the folk tale of the Town Musicians of Bremen (a musical, dramatised fairy tale) created from classroom activity. The context used was a performance shown to $6^{\text {th }}$-grade pupils. (see figure 22).

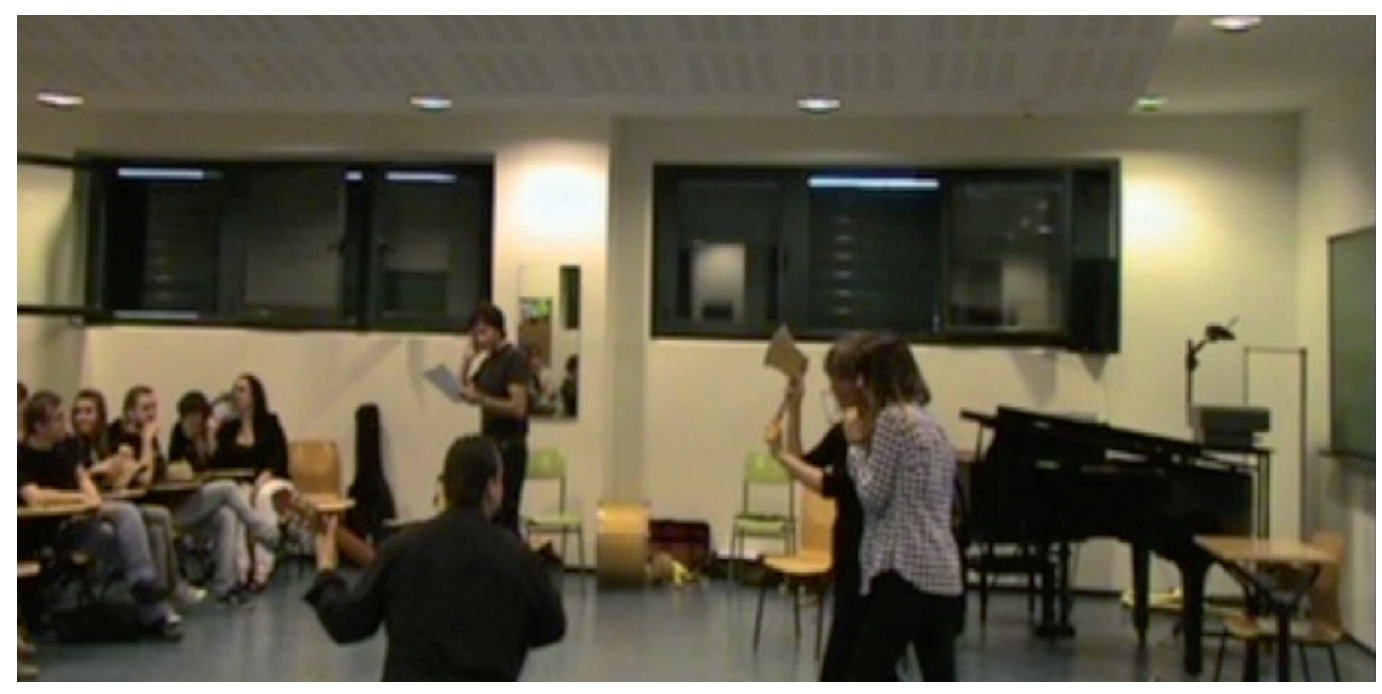

Figure 22. Fifth performance of group 2

The sixth group was called «Presto ma non troppo» and was composed of six members. It was a musical theatre which they called Fate knocks on your door. The story revolves around the life of a famous composer (L.v.Beethoven) who 
visits inhospitable places full of adventures and anecdotes. The group performed different versions of the first movement of Beethoven's Fifth Symphony by combining history and folklore (see figure 23).

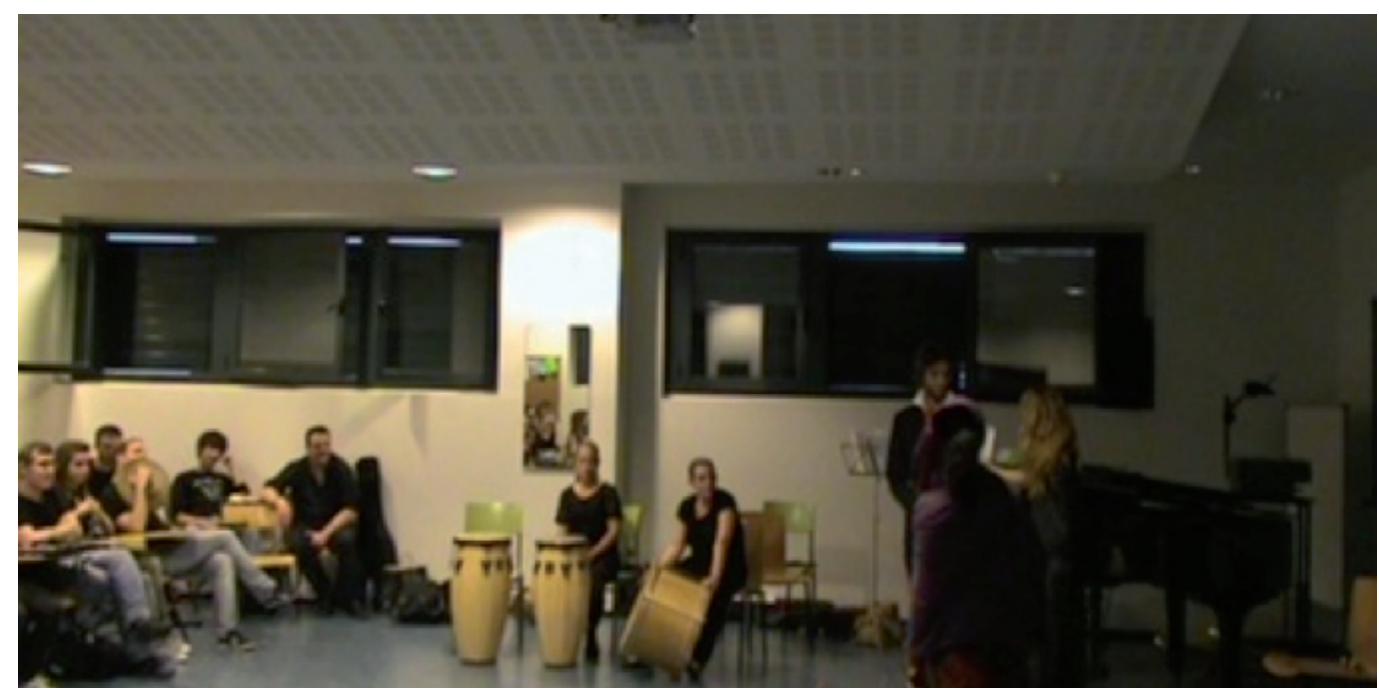

Figure 23. Sixth performance of group 2

The seventh group, «The chameleons», with 10 members, performed a musical theatre based on the history of jazz, ranging from its origins to the formation of black and white groups. The story was based on a musical journey where worksongs were explicitly perceived, as were racial fighting and the jazz genre evolution. This was part of the Music History and Folklore subject matter contents, with dialogues and songs performed in English (see figure 24).

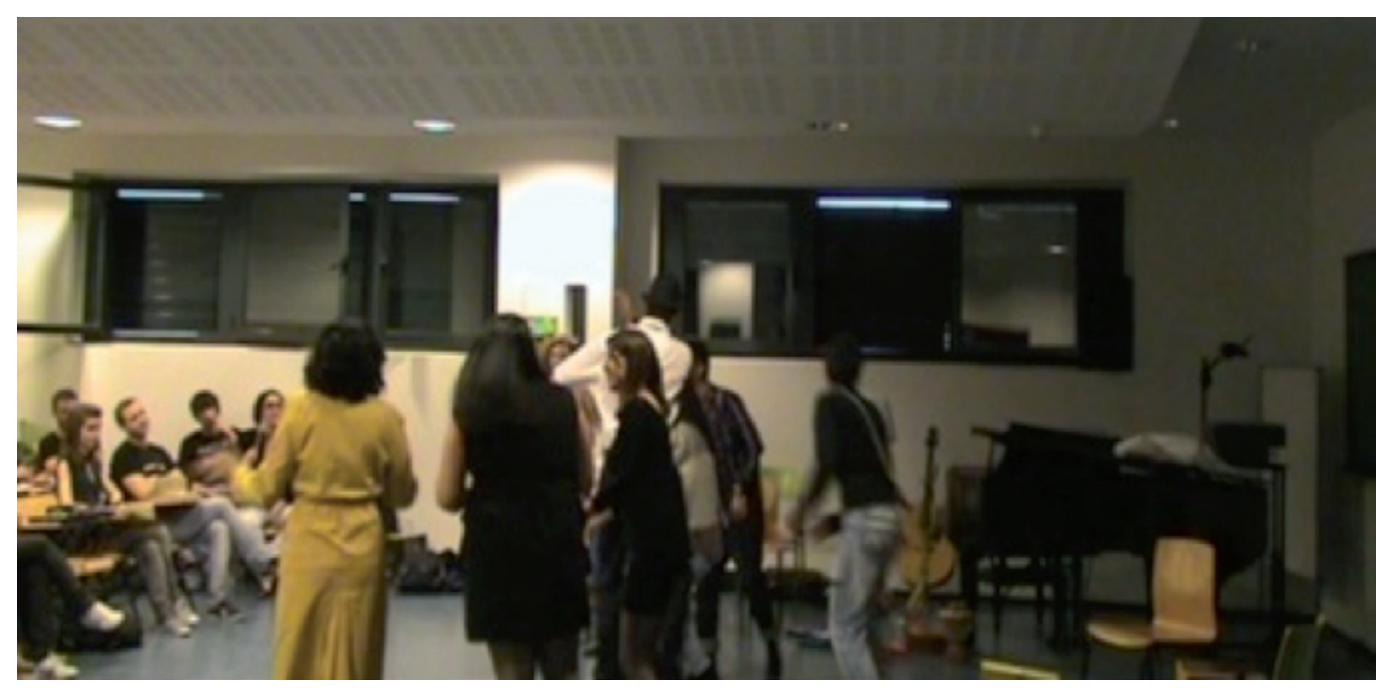

Figure 24. Seventh performance of group 2 
The eighth and final group called «Travelling School», with 11 members, performed a musical theatre set in a television studio. The story was set around some contestants travelling with a time machine to explain to classmates (the audience) where the place was they had travelled to and what it was like. Thus, they attempted to contribute with the content of each subject matter involved in the project (see figure 25).

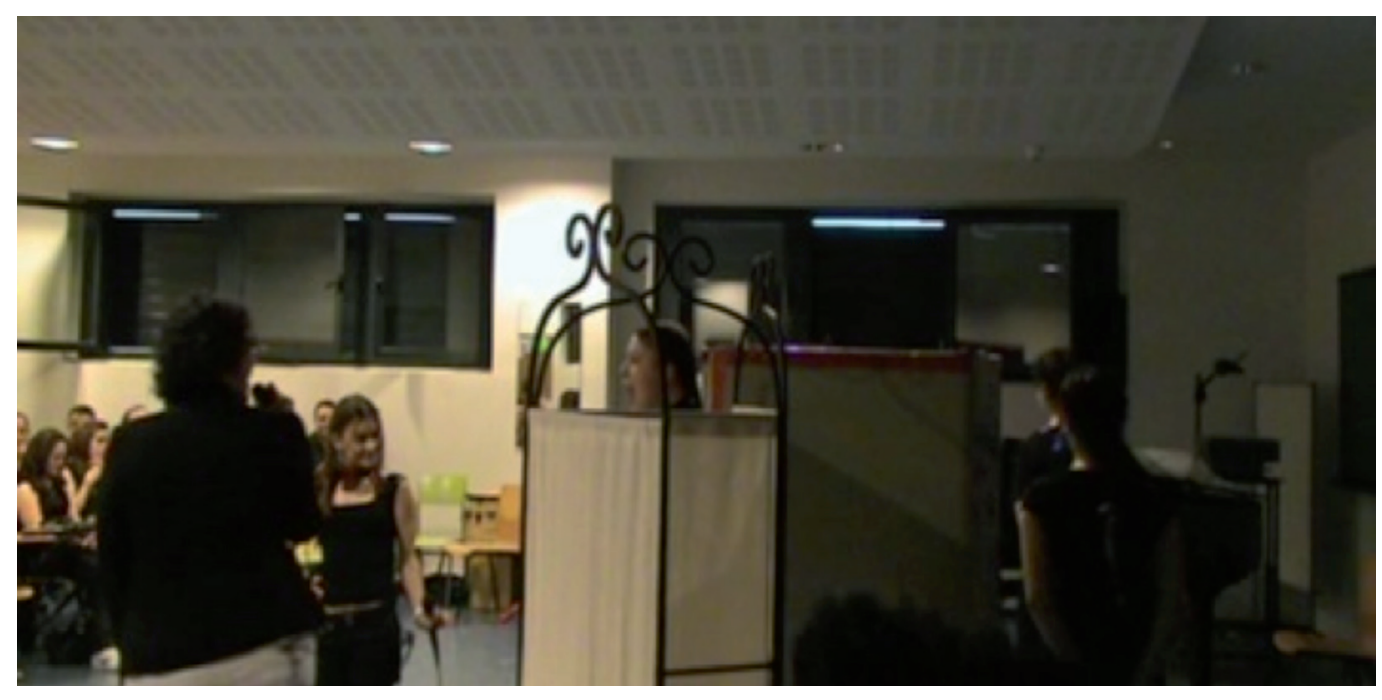

Figure 25. Eight performance of group 2

\section{Conclusions and final considerations}

We present the theoretical and practical framework of a university teaching innovation project, initially called: art as a vehicle for learning, which subsequently became known as the musical theatre as a vehicle for learning-, conducted at the Universities of Castilla-La Mancha and at the Universitat Jaume I of Castellón.

At this point, it is worth considering some benefits and improvements for future editions. Regarding project benefits, students perceived that they must shoulder the responsibility for their work as it had a significant impact on their peers. The project has succeeded in combining the efforts made in the different University subject matters by involving students in a special way.

Overall, the project was welcomed by students, who found it motivating and innovative, among other aspects. As there is ample room for creativity, it became a unique experience for them, and one which combined education aspects with entertainment ones. In addition, as there were video recordings, this meant that students could show their work to friends and family, which helps create a sense of personal satisfaction that evidently goes beyond the classroom walls.

Furthermore, some issues should be taken into account for the future. For example, each group could develop an interdisciplinary teaching unit by considering the 
different subject matters in primary education in an attempt to conceive the primary education curriculum as a whole. It should be noted that with the disappearance of the specialty of teaching music as a degree, this new approach has become a necessity. In the future, many students who take music merely as another subject matter to be passed will argue that «they do not know music», «they will not give music classes», etc. Perhaps the incorporation of this comprehensive curriculum project would be addressed as music, not only in music classes, but also in all the subject matters in the curriculum.

Another aspect to be considered for future editions would be to ensure that all the class sessions were well-structured and to find alternative ways to keep track of each session using different forms of assessment. It would also be necessary to develop educational tools that improve the ways in which each group interacts with peers during performances; in general, certain resources were used in excess, such as clapping in time with the music. It is important to note that not all the students like performing the musical theatre in front of their peers. Therefore, it is apt to argue and think about the benefits of the project for everyone, and to evidence the skills a teacher must possess by comparing them with those developed with the project. In this way, we would provide the project with educational value by moving away from the entertainment ideal. We hope that the project herein presented is of interest to those people who wish to develop similar projects both inside and outside the university. 


\section{References}

Alt, D. (2004). «Triple threat training program's weakest area-reading music: Reinforcing sight reading in the voice studio for singers/actors». Journal of Singing, 60(4), 389-393.

BALOG, J. E. (2005). «A guide to evaluating music theatre singing for the classical teacher». Journal of Singing, 61(4), 401-406.

BERKSON, R. (1990). Music theatre choreography: A practical method for preparing and staging dance in a musical show. London: A \& C Black.

BoARdMAn, S. D. (1987). "Voice training for the musical theater singer». (Doctoral dissertation, University of Cincinnati, 1987). Dissertation Abstracts International, 48 (07), 1574 (UMI No. 8722053).

Boland, R. and Argentini, P. (1997). Musicals! Directing school and community theatre. Lanham, MD: Scarecrow Press.

Boyes, S. E. (2003). «A balancing act: The effects of participation in a school musical on its performers». PhD thesis, University of Toronto (Canadá).

Burnau, J. M. (1966). «Factors concerning the production of the musical in the high school». Dissertation Abstracts, 28 (02), 705. (UMI No. 6615060).

CAtania, C. (2004). «Music theatre as a technical tool and pragmatic business choice for the classical singer». Journal of Singing, 61(2), 185-186.

Costa, A. (1993). «How World-Class Standards Will Change Us», Educational Leadership 50(5), 50-51.

Dillenbourg, P., Baker, M., Blaye, A. and O'Malley, C. (1996). «The evolution of research on collaborative learning». In E. SPADA y P. REIMAN (Eds.), Learning in Humand and Machines; Towards an Interdisciplinary Learning Science (pp. 189-211). Oxford, UK: Elsevier.

Drake, S.M. y Burns R.C. (2004). Meeting Standards Through Integrated Curriculum. Alexandria: ASCD.

Duplass, J. (2006). Middle and High School Teaching: Methods, Standards, and Best Practices. Boston: Houghton Mifflin Company.

ENGEL, L. (1966). Planning and producing the musical show. New York: Crown.

- (1983). Getting the show on: The complete guidebook for producing a musical in your theatre. New York: Schirmer.

FIELDS, J. C. (1970). «The musical theatre production: A guide for the high school director». Dissertation Abstracts International, 31 (08), 4320 (UMI No. 7026233).

FilichiA, P. (1997). Let's put on a musical! How to choose the right show for your theater. New York: Back Stage Books.

Frederickson, M. (2010). «The National Standards for Music Education: A Transdisciplinary Approach in the Applied Studio». Music Educators Journal, 97(2), 44-50. DOI: 10.1177/0027432110387829.

Grote, D. G. (1986). Staging the musical: Organizing, planning, and rehearsing the amateur production. New York: Prentice-Hall.

HeINIG, R. B. (2001). «Stagecoach theatre schools: England's franchised musical theatre training». Stage of the Art, 12(4), 23-27. 
HoAre, W. (1993). The musical director in the amateur theatre. Malvern, UK: J. Garnet Miller.

HowARD, P. M. (1990). «The development of a standard form to identify performance problems in high school productions of musical theatre with application to selected works». Dissertation Abstracts International, 51 (05), 1541.

Hower, E. (1999). «Creating an opera with seventh graders». The Recorder, 41(3), 24-27.

JANICKI, L. J. (1982). «Musical theatre in high school». Masters Abstracts, 21 (01), 112 (UMI No. 1319309).

Johnson, D. W.; Johnson, R. T.; Smith, K. (1991). Active Learning: Cooperation in the College Classroom. Edina, MN: Interaction Book Company.

LAster, J. (2001). So you're the new musical director! An introduction to conducting a Broadway musical. Lanham, MD: Scarecrow Press.

LeIst, F. (1958). «Broadway comes to high school». The School Musician, 29(8), 22-23, 51.

Llopis Bueno, E. (2011). «Hacer música... para comprometerse con la realidad». Érik. Eufonía, 51, 34-43.

Llopis Bueno, E., Roselló, E. Y Villarroya, J. (2009). “"Fills de Kassim” un musical para educar en la convivencia cultural». Eufonía, 47, 104-116.

Lucha-Burns, C. (1986). Musical notes: A practical guide to staffing and staging standards of the American musical theatre. Westport, CN: Greenwood Press.

LyNCH, R. C. (1994). Musicals! A complete selection guide for local productions. Chicago: American Library Association.

Miller, S. (2000). Deconstructing Harold Hill: An insider's guide to musical theatre. Portsmouth, NH: Heinemann.

NovaK, E. A. (1988). Performing in musicals. New York: Schirmer.

Oneglia, M. F. (1973). «Directing a musical show». The Instrumentalist, 28(5), 44-45.

PANITZ, T. (1996). «Collaborative versus cooperative learning - A comparison of the two concepts which will help us understand the underlying nature of interactive learning». http://home.capecod.net/tpanitz/tedarticles/whyfewclusers.htm (october 2010).

Pérez Aldeguer, S. (2012). «Una forma creativa de mejorar la evaluación y clasificar las prácticas en educación musical». Revista Electrónica Iberoamericana sobre Calidad, Eficacia y Cambio en Educación-REICE, 10(2), 148-158.

Pino Juste, M. y Soto Carballo, J. (2010). «Ventajas e inconvenientes de la tutoría grupal como estrategia docente: estudio de caso». Bordón, 62(1), 155-166.

SAgolla, L. T. (1992). «Choreography in the American musical, 1960-1969: The dramatic functions of dance». Dissertation Abstracts International, 53 (02), 334 (UMI No. 9218711).

Sample, A. D. (1964). «A Study of the Suitability of Selected Musicals for Performance by the High School Student». Unpublished Doctoral Dissertation, Columbia University.

Sarmiento, P. (2012a). «La Ópera, un Vehículo de Aprendizaje (Lóva)». Eufonía, $55,40-47$.

- (2012b). «El empoderamiento según LóvA». Aula de innovación educativa, 213-214, 32-37. 
SJoerdsma, R. D. (2004). «Promoting vocal health in the production of high school music theater». Journal of Singing, 60(3), 223-335.

SNIDER, C. D. (1995). «Teaching Broadway: Musical theatre pedagogy in the classroom». Tesis de la Universidad del Estado de San José.

Timmons, D. F. (2004). «Musical theater in the twenty-first century community college». Dissertation Abstracts International, 64 (10), 3533.

Traver, J. A. y Rodríguez, M. (2011). Los cuadernos de aprendizaje en grupo. Valencia: La Xara.

TRYTTEN, K. (1988). «So you're putting on a musical?». The Instrumentalist, 43(3), 29-30.

Van Houten, K. E. Z. (1999). «High school musical theatre and the meaning students give to their involvement». Dissertation Abstracts International, 60 (06), 1959.

Walsh, D. and Platt, L. (2003). Musical theatre and American culture. Westport, CT: Praeger.

Watkins, R. L. (2005). «The musical theater experience and the extent to which it affects high school students». Dissertation Abstracts International (UMI No. 3199170).

Williams, T. S. (2003). «Responsibilities and preparation of public school secondary music specialists in teaching musical theatre». Dissertation Abstracts International, 65 (03), 763. 


\section{Figures index}

Figure 1. Basic skills of the subject (Pérez Aldeguer, 2012:152) _ . . . 20

Figure 2. Final concert of the pilot project $\ldots \ldots \ldots \ldots \ldots \ldots \ldots \ldots . \ldots \ldots \ldots$

Figure 3. Summary of the pilot project $\ldots \ldots \ldots \ldots \ldots \ldots \ldots \ldots \ldots \ldots$

Figure 4. Summary of collaborative project: Group $1 \ldots \ldots \ldots \ldots \ldots$

Figure 5. First performance by group PR2 $\ldots \ldots \ldots \ldots \ldots \ldots \ldots \ldots$

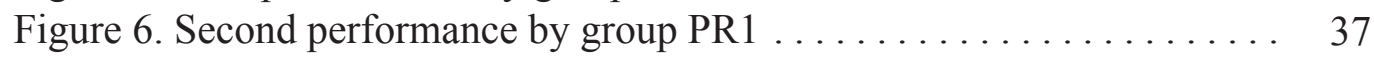

Figure 7. Third performance of all students together ........... 38

Figure 8. Subjects involved in the cooperative project of group $2 \ldots \ldots \ldots 44$

Figure 9. Summary of the cooperative project in group $2 \ldots \ldots \ldots \ldots 45$

Figure 10. Virtual class of one of the participant subjects . . . . . . . 45

Figure 11. The project documents in the Virtual Classroom . . . . . . . . . 46

Figure 12. Model of a project contract $\ldots \ldots \ldots \ldots \ldots \ldots \ldots \ldots \ldots$

Figure 13. Model of a minutes of session $\ldots \ldots \ldots \ldots \ldots \ldots \ldots \ldots . \ldots 47$

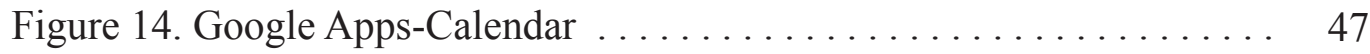

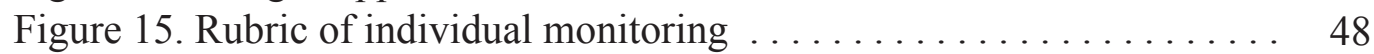

Figure 16. Rubric of group monitoring . . . . . . . . . . . . . . 49

Figure 17. Rubric of performance-exam $\ldots \ldots \ldots \ldots \ldots \ldots \ldots \ldots \ldots$

Figure 18. First performance of group $2 \ldots \ldots \ldots \ldots \ldots \ldots \ldots \ldots \ldots \ldots$

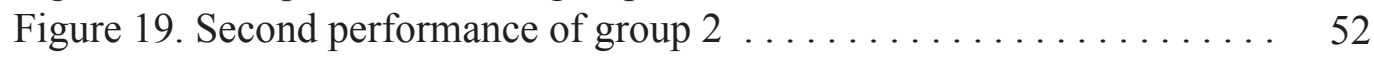

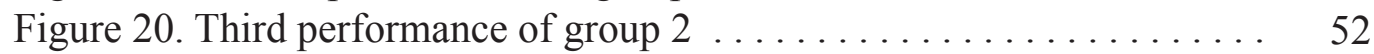

Figure 21. Fourth performance of group $2 \ldots \ldots \ldots \ldots \ldots \ldots \ldots \ldots$

Figure 22. Fifth performance of group $2 \ldots \ldots \ldots \ldots \ldots \ldots \ldots \ldots \ldots$

Figure 23. Sixth performance of group $2 \ldots \ldots \ldots \ldots \ldots \ldots \ldots \ldots \ldots$

Figure 24. Seventh performance of group $2 \ldots \ldots \ldots \ldots \ldots \ldots \ldots \ldots$

Figure 25. Eight performance of group $2 \ldots \ldots \ldots \ldots \ldots \ldots \ldots$

\section{Tables index}

Table 1. Technical Script $\ldots \ldots \ldots \ldots \ldots \ldots \ldots \ldots \ldots \ldots \ldots \ldots . \ldots \ldots$

Table 2. Distribution of roles in the collaborative project $\ldots \ldots \ldots \ldots \ldots 35$

Table 3. Example of roles in collaborative project $\ldots \ldots \ldots \ldots \ldots \ldots . \ldots . \ldots . \ldots . \ldots$

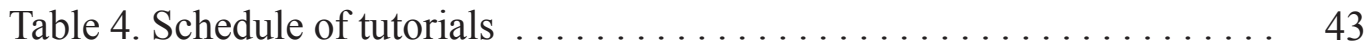

